\title{
General Legitimacy of Fudicial Review and the Fundamental Basis of Constitutional Law
}

\author{
LUC B. TREMBLAY*
}

\begin{abstract}
Four questions dominate normative contemporary constitutional theory: What is the purpose of a constitution? What makes a constitution legitimate? What kinds of arguments are legitimate within the process of constitutional interpretation? What can make judicial review of legislation legitimate in principle? The main purpose of this text is to provide one general answer to the last question. The secondary purpose is to show how this answer may bear upon our understanding of the fundamental basis of constitutional law. These two purposes should suggest particular answers to the first three questions.
\end{abstract}

Traditionally, the answers to the question of legitimacy of judicial review of legislation have been conceived as solutions to what has been called the 'countermajoritarian difficulty'. ${ }^{1}$ On this assumption, no law is (acceptable as) legitimate unless it expresses the will of the representatives of the people as determined in accordance with the majority rule. Since judges do not represent the people (whatever that means), not being elected and not otherwise personifying the citizenry, and since they are not accountable to the people or to citizens (they are independent and appointed for a long term), judicial review of legislation constitutes a 'countermajoritarian force' in a system of governance committed to democracy. ${ }^{2}$ It follows that those who claim that this institution is legitimate have the burden of showing that it can be reconciled with the underlying assumptions of democratic governance. The various answers to the question of legitimacy of judicial review have generally postulated that no form of judicial review of legislation is acceptable as legitimate unless it can be shown that it is specifically authorized by some positive democratic legitimating fact (or set of

\footnotetext{
* Faculty of Law, University of Montreal. Different versions of this text have been presented to workshops and seminars, notably at the Center for Interdisciplinary Research of Bielefeld University, at the Legal Theory Workshop of the University of Toronto, at the Congress of the Quebec Society of Philosophy and at the Conference on the 20th Anniversary of the Canadian Charter of Rights and Freedoms. I have greatly benefited from the comments and criticisms made by the colleagues who have participated in these forums. I wish to thank my colleagues Jean Leclair and Charles Blattberg for their judicious comments on a previous draft of this text. I also thank the Social Sciences and Humanities Research Council of Canada for its Financial support.

${ }^{1}$ See A. Bickel, The Least Dangerous Branch (New Haven: Yale University Press, 1962) at 16-23.

${ }^{2}$ Ibid. 
facts). They have sought to establish what I shall call the 'specific legitimacy of judicial review'.

In this text, I shall argue that the institution of judicial review of legislation does not need to be specifically authorized in order to be accepted as legitimate. The mere fact that the judiciary already exercises effective coercive power and political authority within society constitutes a sufficient reason to recognize what I shall call the general legitimacy of judicial review. My argument does not deny that some form of specific authorization could support judicial review and enhance its moral legitimacy. My claim is that such support is not necessary: judicial review of legislation is legitimate in principle. Indeed, I shall argue that it is not only morally permissible, it might be required as a matter of political morality.

One might think that this question has become academic in countries where judicial review is established as constitutional practice. The American constitutional scholar Michael J. Perry, for example, has argued that the questions whether 'We the people' ever established the practice of judicial review and whether judicial review is, all things considered, a good idea are not for the people of the United States now living, 'live questions':

Judicial review has been a bedrock feature of our constitutional order almost since the beginning of our country's history. It would be startling, to say the least, were we Americans to turn skeptical about the idea of judicial review ... For us, the live questions about judicial review are about how the power of judicial review should be exercised. $^{3}$

Similarly, Canadian constitutional scholars Patrick Monahan and Andrew Petter have argued that the issue of legitimacy 'does not centre on whether to have judicial review at all; this "big question" was settled by the enactment of the Charter in 1982':

What the enactment of the Charter did not resolve was the subsidiary, but nonetheless important, issue of what are the inherent limits to judicial review in the Canadian context. Once it is acknowledged that such limits exist, then the issue of legitimacy is joined. The very act of delineating limitations on judicial review requires the identification of those forms of judicial review that fall outside of the limits and are therefore inappropriate or 'illegitimate'. ${ }^{4}$

This position is misleading. The answers to the questions 'How should judicial review be exercised?' and 'What are its inherent limitations?' depend on the answers to the big questions - whether judicial review can be made legitimate at all, whether it is a good idea and whether it has been historically established by 'We the people'. Where the institution of judicial review is accepted as legitimate,

\footnotetext{
${ }^{3}$ M.J. Perry, 'What is 'the Constitution'? (and Other Fundamental Questions)' in L. Alexander, Constitutionalism, Philosophical Foundations (Cambridge: Cambridge University Press, 1998) at 120. But see M. Tushnet, Taking the Constitution Away from the Courts (Princeton: Princeton University Press, 1999).

${ }^{4}$ P. Monahan and A. Petter 'Developments in Constitutional Law: The 1985-86 Term' (1987) 9 Supreme Court Law Review 69 at 74.
} 
the determination of its proper limitations, including correct modes of interpretation and deference, is constrained by the values and considerations that have justified it in the first place, that is, by the answer given to the more abstract, normative and speculative question of legitimacy. For example, if the legitimacy of judicial review of legislation were a matter of being enshrined in a constitution enacted by the people, then the limits of this power might well be determined in accordance with what was originally intended. If it were a matter of contemporary acceptance, then the limits of the power to review legislation might well be determined in accordance with contemporary standards. Of course, if no form of judicial review can be made morally permissible in principle, then no particular limitation on this power can legitimize those forms of judicial review that would fall inside the alleged limits. ${ }^{5}$

It is therefore important to determine whether, and on what basis, judicial review of democratically enacted legislation can be made morally permissible in principle. My argument is divided into three sections. In section 1, I will examine the structure and the limits of the theories seeking to establish the specific legitimacy of judicial review. In section 2, I will establish the general legitimacy of judicial review of legislation. In section 3, I will determine the impact the general legitimacy of judicial review might have on our representation of the fundamental basis of constitutional law. In a short conclusion, I suggest some answers to the three other questions that dominate normative contemporary constitutional theory: What is the purpose of a constitution? What makes a constitution legitimate? What kinds of arguments are legitimate within the process of constitutional interpretation?

\section{The Specific Legitimacy Thesis}

The question of political legitimacy is raised when a person or an institution claims to have authority over individuals or when it has effective power in the sense of having its actions and decisions backed up by collective force. This question seeks to determine the moral considerations by virtue of which this person or institution is entitled to command, that is, the considerations by virtue of which the person's or institution's actions or decisions are morally permissible. This idea must minimally imply that it is in principle morally wrong for someone to interfere with legitimate political actions or decisions unless one can show that such interference is itself legitimate, that is, morally permissible. Thus, the mere fact that an action or a decision is legitimate provides a moral reason to treat it in a certain way, namely, to refrain from interfering with it. ${ }^{6}$

In general, the answer to this question has taken the form of a moral principle indicating the positive fact (or set of facts) by virtue of which political actions or

\footnotetext{
${ }^{5}$ Certain contemporary scholars have powerfully argued against the institution of judicial review. See, for example, Jeremy Waldron, Law and Disagreement (Oxford: Oxford University Press, 1999) See also Tushnet, above n 3.

${ }^{6}$ On the link between political legitimacy and obligation to obey, see, in general, A.J. Simmons, Moral Principles and Political Obligations (Princeton: Princeton University Press, 1979).
} 
decisions are specifically authorized. Consent theory, for example, has supplied such a principle. It has stated that the fact that individual citizens have or, under certain conditions, would have voluntarily consented to be governed by a given form of government constitutes a sufficient reason to regard the actions and decisions of that government as specifically authorized. Without such actual (or hypothetical) consent, laws enacted by such a government would not be morally permissible. Democratic theory supplies another principle. It states that the fact that a given piece of legislation has a democratic pedigree (leaving aside for the moment what that means) makes it morally permissible. Other principles may point to other facts such as immemorial customs, divine law, the law of nature, a constitution, and so on. These answers seek to establish what I shall call a specific legitimacy of political authority. They point to positive legitimating facts.

The judiciary exercises effective coercive power and has political authority within society. By virtue of what considerations can we say that the power of this authority is legitimate and, consequently, that its actions and decisions are morally permissible? The modern answer has taken the form of principles establishing the specific legitimacy of judicial power. I will call it the 'Specific Legitimacy Thesis' (SLT). It can be summarized into four propositions.

SLT1: The judiciary has no inherent legitimacy. If it ever exists, its legitimacy must derive from considerations that have nothing to do with the character, the wisdom, the moral expertise or the sort of persons it is composed of, nor from the kind of institution it is by divine law, tradition or nature.

SLT2: Specific legitimacy of judicial power is conditioned by the 'rule of law'. This means three things. First, the constitution of the judiciary (its structure and composition) must be 'according to law'. Second, the judicial process (the manner and procedures) by virtue of which judicial decisions are reached must also be 'according to law'. Third, and most importantly for our purposes, the content and substance of judicial decisions must be in accordance with the law. Although contested, the concept of the rule of law entails two basic ideas: first, governmental actions and decisions must be 'rational', that is, based on reasons, and, second, the reasons for governmental actions and decisions must be, in a certain sense, 'legal'. It follows that special legitimacy of judicial power is conditioned by rational judicial decisions that are based upon reasons that are, in a certain sense, 'legal'.

The rule-of-law condition is formal. It holds that legitimacy of judicial power (partly) derives from the 'legal' character of the justification of the decisions made by the courts, independently of their content, intrinsic worth or consequences. Within modern legal theory, this condition has often been conceived as sufficient: mere legality would establish the specific legitimacy of judicial power. This has been known as 'legalism'. Yet mere legality cannot be accepted as a

\footnotetext{
${ }^{7}$ On the concept of the Rule of Law, see L.B. Tremblay, The Rule of Law, Fustice, and Interpretation (Montreal: McGill-Queen's University Press, 1997) at 29-34.
} 
sufficient condition. Imagine a case in which a dictator would use its legal prerogatives to command the death of all blue-eyed girls under the age of six. Other things being equal, no one could seriously claim that judges who would enforce this command would act in a legitimate way. One might certainly claim that such judges would act within the law and, accordingly, that their decisions would be 'legal'. But to infer from this form of legality the proposition that the decision is legitimate would be non sequitur. The judiciary has no more legitimacy than the law that justifies its decisions. Thus, unless the law used as reason for decision is made legitimate in accordance with some material normative standard, the decisions it justifies cannot be regarded as legitimate. Two other propositions are needed:

SLT3: The law providing the reasons for judicial actions and decisions must itself be legitimate. Since the judiciary has no inherent legitimacy (SLT1) and since its legitimacy is conditioned by the rule of law (SLT2), it has no more legitimacy than the law that governs its constitution, its process and its actions and decisions.

SLT4: The law is legitimate if, and only if, it is constituted by political decisions that have a certain democratic pedigree (whatever that specifically means). Indeed, in the abstract, legitimacy of law may not be a matter of democratic entitlement (it may depend on its conformity with natural law, for example). But, within modernity, it has been generally postulated that the specific legitimacy of judicial actions and decisions is ultimately a matter of democratic entitlement. This has derived from a commitment to the separation of powers doctrine read in accordance with the ideas of popular and national sovereignty that underlie the modern idea of democracy.

These four propositions express the modern justification for the specific legitimacy of judicial actions and decisions. Indeed, they clearly show why judicial enforcement of democratically enacted legislation against citizens has generally been conceived as legitimate within democratic society. When judges enforce a piece of legislation that has a democratic pedigree, their reasons for decision are both legal (SLT2) and legitimate (SLT3 and SLT4).

But we are not so much concerned with judicial decisions that enforce democratically enacted legislation as with judicial decisions that do not enforce it. When judges decide not to enforce against citizens a relevant piece of legislation that has been enacted by a democratic body, they do not recognize as good reason for their decision a legitimate law that should otherwise apply to the case at hand. This is why judicial review is generally conceived as a countermajoritarian force within a system of governance committed to democracy. Moreover, even if majoritarianism did not constitute the best normative theory of democracy for the purposes of political legitimacy, judges could not justify their decisions not to enforce legislation by an appeal to their own democratic pedigree: as we know, judges do not personify the people, do not represent them, are not elected and are not formally accountable to the electorate. The question, then, is to determine the considerations by virtue of which judicial review of democratically 
enacted legislation can be conceived and accepted as legitimate within the framework of the Specific Legitimacy Thesis.

Various answers have been put forward. The traditional strategy has been to ground the specific legitimacy of judicial review on the fact that the reasons justifying judicial decisions not to enforce democratically enacted legislation are both legal and superior to legislation within the formal hierarchy of legal sources or in the chain of formal legal validity. Thus, judicial review would be specifically authorized when it is based upon the norms of a valid 'supra-legislative' written constitution. I shall call this thesis the 'Traditional View' on the specific legitimacy of judicial review. The reasoning is quite straightforward: it is well accepted that where two laws conflict, the judiciary must decide in accordance with the law that is superior in the hierarchy of legal sources or in the chain of formal legal validity. Thus, if there is a conflict between a written constitutional rule and a piece of legislation, and if the relevant legal system establishes that the constitution is superior to legislation in the formal hierarchy of sources or in the chain of formal legal validity, then the judiciary must decide in accordance with the constitution. It must not enforce that piece of legislation-it may declare it unconstitutional, invalid, inoperative or of no force and effect. ${ }^{8}$

The problem with the Traditional View, however, is that it does not meet the requirements of the Specific Legitimacy Thesis. It might be true, of course, that the norms deriving from the constitution may constitute valid legal reasons within the ambit of SLT2. But it does not follow that such reasons morally authorize the courts to set aside enacted legislation that does possess a democratic pedigree within the ambit of SLT4. For this reason, the Traditional View does not resolve the antidemocratic difficulty. It just confirms it. The Traditional View is formal. It seeks to ground the legitimacy of judicial review on the 'legal' character of the reasons for decisions. Accordingly, if a constitution provided that 'Parliament shall not help the poor and the sick', it would follow that judicial decisions not to enforce a democratically enacted legislation purporting to help the poor and the sick should be accepted as legitimate within a democratic society. This is not reasonable. The Traditional View is no more satisfying than the form of legalism criticized above. It meets the rule-of-law condition, but overlooks the fact that the question of legitimacy is a matter of political morality, not merely of legality.

For this reason, a second strategy has been adopted. It argues that judicial review of democratically enacted legislation can be legitimized when it is based upon written constitutional norms that have a legal character (SLT2) and that have become legitimate (SLT3) by virtue of some democratic pedigree (SLT4).

\footnotetext{
${ }^{8}$ The Traditional View has dominated Canadian constitutional law and theory at least until 1982 . The specific legitimacy of judicial review was conceived as conditioned by the rule-of-law condition. Judicial review was conceived as permissible by virtue of constitutional texts providing the criteria of formal validity of provincial and federal legislation. This written constitution was superior in legal authority to provincial and federal legislation by virtue of the fact that it had been enacted by the Imperial Parliament, recognized by Anglo-Canadian law as supreme within the formal hierarchy of legal sources. See, for example, B.L. Strayer, The Canadian Constitution and the Courts: the Function and Scope of fudicial Review (3rd edn, Toronto: Butterworths, 1988).
} 
There are many versions of this argument depending on what is seen as constituting a legitimate democratic Constitution, but most versions claim that constitutional democratic legitimacy must be source-based and derive from an original act of popular consent. Constitutions that have been explicitly drafted, promulgated, ratified or otherwise explicitly or tacitly agreed to or approved by the will of the majority of the people or of their elected representatives at the time of enactment, would possess the required democratic pedigree. Therefore, if the constitution is superior within the chain of formal legal sources and if it has a democratic pedigree, judicial review based upon this constitution should be accepted as legitimate. I shall call this argument the 'Dominant View' on the specific legitimacy of judicial review.

The Dominant View is well-known within American constitutional law, at least since the famous case Marbury $\mathrm{v}$ Madison. ${ }^{9}$ In this case, Chief Justice Marshall held that federal courts have the authority, indeed the duty, not to enforce congressional legislation that is inconsistent with the American Constitution. The reasoning apparently came within the Specific Legitimacy Thesis. SLT2 was established as follows: the judiciary must act in accordance with the law; when two laws are in conflict, the law that is superior within the hierarchy of legal sources should take priority; the Constitution is law; the Constitution is superior to legislation within the legal system; the courts must set aside legislation that conflicts with the Constitution. ${ }^{10}$ SLT3 and SLT4 were established by asserting that the people have an original right to establish for themselves the form of government they think best, to write it down into a written constitution and to contemplate it as forming the fundamental and paramount law of the nation. ${ }^{11}$

\footnotetext{
${ }^{9} 5$ U.S. (1 Cranch) 137 (1803). See also Hamilton's argument in M.E. Webster, The Federalist Papers (Bellevue: Washington, Merril Press, 1999) 78.

${ }^{10}$ The relevant passages are the following: 'Certainly all those who have framed written Constitutions contemplate them as forming the fundamental and paramount law of the nation, and consequently the theory of every such government must be that an act of the Legislature repugnant to the Constitution is void. This theory is essentially attached to a written constitution, and is consequently to be considered, by this court, as one of the fundamental principles of our society. It is not therefore to be lost sight of in the further consideration of this subject. ... It is emphatically the province and duty of the judicial department to say what the law is. Those who apply the rule to particular cases, must of necessity expound and interpret that rule. If two laws conflict with each other, the courts must decide on the operation of each. So if a law be in opposition to the constitution; if both the law and the constitution apply to a particular case, so that the court must either decide that case conformably to the law, disregarding the constitution; or conformably to the constitution, disregarding the law; the court must determine which of these conflicting rules governs the case. This is of the very essence of judicial duty. If then the courts are to regard the constitution; and the constitution is superior to any ordinary act of the legislature; the constitution, and not such ordinary act, must govern the case to which they both apply ... The judicial power of the United States is extended to all cases arising under the Constitution. Could it be the intention of those who gave this power to say that, in using it, the Constitution should not be looked into? That a case arising under the Constitution should be decided without examining the instrument under which it arises? This is too extravagant to be maintained'. Ibid at 176-79.

${ }^{11}$ The relevant passages are the following: 'That the people have an original right to establish, for their future government, such principles as, in their opinion, shall most conduce to their own happiness, is the basis on which the whole American fabric has been erected. The exercise of this original right is a very great exertion; nor can it nor ought it to be frequently repeated. The principles, therefore, so established are deemed fundamental. And as the authority from which they proceed, is supreme, and can seldom act, they are designed to be permanent. ... It is apparent that the framers of the Constitution contemplated that instrument as a rule for the government of courts, as well as of the Legislature' ibid, at 176 and 180. See also, above n 10.
} 
The Dominant View has been recently accepted by the Supreme Court of Canada. Since 1982, the Supreme Court has clearly sought to establish the legitimacy of the written Constitution in accordance with SLT3 and SLT4. ${ }^{12}$ In various cases, it has asserted that the reasons that justify judicial review of democratically enacted legislation have been determined and accepted by the elected representatives of the people of Canada. The Court said, for example, that:

It ought not be forgotten that the historic decision to entrench the Charter in our Constitution was taken not by the courts but by the elected representatives of the people of Canada. It was those representatives who extended the scope of constitutional adjudication and entrusted the courts with this new and onerous responsibility. Adjudication under the Charter must be approached free of any lingering doubts as to its legitimacy. ${ }^{13}$

The Court insisted on the fact that the proclamation of the Constitution Act, 1982, in which we find the Canadian Charter of Rights and Freedoms, was legitimate, although formally enacted by the Parliament of the United Kingdom:

the legitimacy as distinguished from the formal legality of the amendments derived from political decisions taken in Canada within a legal framework which this Court, in the Patriation Reference, had ruled was in accordance with our Constitution. ${ }^{14}$

Similarly, the Supreme Court retrospectively justified the democratic legitimacy of the Constitution Act, 1867, in accordance with the Dominant View. In the Quebec Secession Reference, for example, the Court argued that the creation of Canada in 1867, although legally instituted by an Imperial Act, the British North America Act (now the Constitution Act, 1867), resulted from 'an initiative of elected representatives of the people then living in the colonies scattered across part of what is now Canada. It was not initiated by Imperial fiat ${ }^{15}$ Not

\footnotetext{
${ }^{12}$ In 1982, the United Kingdom Parliament enacted the Canada Act 1982, UK Stats 1982, c. 11, which terminated its authority over Canada. The Act included the Constitution Act, 1982 (incorporated as Schedule B to the Canada Act 1982), which contained, among other things, the Canadian Charter of Rights and Freedoms and the amending formula. The legitimacy of judicial review became an important constitutional question for two reasons: the scope of judicial review was broadened, especially because of the incorporation of the Charter of rights, and the courts could hardly morally justify its power to review legislation on the ground that the Constitution Act, 1982 had been enacted by the imperial Parliament (that would have maintained the ultimate authority the United Kingdom Parliament over Canada). Of course, section 52 of the Constitution Act, 1982, stipulates that the Constitution of Canada is the supreme law of Canada and that 'any law that is inconsistent with the provisions of the Constitution is, to the extent of the inconsistency, of no force and effect'. But section 52 cannot justify the legitimacy of judicial review based upon the Constitution. It might provide, if anything, the legal basis of judicial review in Canada. I have examined these questions in L.B. Tremblay 'Marbury v. Madison and Canadian Constitutionalism: Rhetoric and Practice', The George Washington Law Review (forthcoming).

${ }^{13}$ Motor Vehicle Act (B.C.) Reference [1985] 2 SCR 486 at 497.

${ }^{14}$ Reference re Secession of Quebec [1998] 2 SCR 217 at para 47. In the first case dealing with the Canadian Charter of Rights and Freedoms, Law Society of Upper Canada v Skapinker [1984] 1 SCR 357 at 365, the Supreme Court of Canada recalled that the Charter was adopted first as an appendage to the Resolution of Parliament on December 8, 1981 and then as an appendix to the Canada Act 1982, UK Stats 1982, c. 11. The Court wanted to reduce the legitimating force of the fact of being enacted in the United Kingdom: 'It is a part of the constitution of a nation adopted by constitutional process which, in the case of Canada in 1982, took the form of a statute of the Parliament of the United Kingdom. The adoptive mechanisms may vary from nation to nation. They lose their relevancy or shrink to mere historical curiosity value on the ultimate adoption of the instrument as the Constitution. The British North America Act of 1867 was such a law, albeit but a statute of the Parliament of the United Kingdom and albeit incomplete in the absence of an intra-national amending mechanism'.

${ }^{15}$ Reference re Secession of Quebec [1998] 2 SCR 217 at para 35.
} 
only were the resolutions that subsequently became the British North America Act approved by local delegates, but they were confirmed by Local Parliaments before being translated into law by the Imperial Parliament.

But there is at least one important objection against the Dominant View. The mere fact that a constitution was drafted, promulgated, ratified or otherwise explicitly or tacitly approved by the will of the majority of the people or of their elected representatives at the time of enactment does not necessarily entail that it ought to prevail over subsequent legislation that has been similarly drafted, promulgated, ratified or otherwise explicitly or tacitly approved. Accordingly, the legitimacy of judicial review may not follow from the democratic character of the constitution. Insofar as legitimacy of the judicial power is conditioned by legal reasons that have been made legitimate by virtue of some consent or decision of the people or of their elected representatives, it should follow, as a matter of coherence, that the courts must recognize as legitimate reason for decision the law that best represents the consent of the people or of their elected representatives at the time of decision. The mere fact that a democratically enacted constitution has been recognized as supra-legislative within a formal hierarchy of legal sources cannot be a sufficient reason to set aside a law that represents better what, at the time of judicial decision, the people or their elected representatives have consented to. Therefore, in principle, where there is a conflict between two laws, the court should uphold the law that best represents the will or judgment of the contemporary body of citizens. Otherwise, the will or judgement of past citizens would limit or prevent the power of present-day citizens to democratically determine for themselves what kinds of policies, values, interests and ends should be promoted today in the interests of the community. ${ }^{16}$

This objection to judicial review is typical within sovereignty theory. The power of a sovereign, be it a person or a democratic people, has been conceived as 'continuous', both as a matter of logic and political morality. Accordingly, a sovereign people should never be bound by its previous political decisions. ${ }^{17}$ Indeed, this has been a constitutive proposition of the doctrine of parliamentary sovereignty in the United Kingdom. ${ }^{18}$ This is also typical within democratic theory. Bruce Ackerman, for example, has called this the 'principle of the last word':

Other things being equal, it would be antidemocratic for the courts to reject a later decision of a representative government simply because it was inconsistent with an earlier one. The People must reserve the right to change their minds-otherwise we have ancestor worship, not democracy. ${ }^{19}$

\footnotetext{
${ }^{16}$ This argument might not hold when legislation has been enacted prior to the enactment of the constitution.

${ }^{17}$ This proposition is well-known within sovereignty theory. A sovereign has supreme authority within the State and its power is conceived as perpetual, inalienable, indivisible and absolute. It is accountable to no one, but itself. It is above the law and its will is the ultimate source of all laws. It can make and unmake any law. It follows that a sovereign people cannot be bound by its prior political decisions.

${ }^{18}$ See A.V. Dicey, Introduction to the Study of the Law of the Constitution (10th edn, London: Macmillan Education Ltd, 1959) at 64-70.

${ }^{19}$ See B. Ackerman 'The Storrs Lectures: Discovering the Constitution' (1884) 93 Yale Lf 1013 at 1046. Of course, Ackerman's thesis based upon democratic dualism is to show that other things are not always equal.
} 
Now ancestor worship raises what he calls an 'intertemporal difficulty'. ${ }^{20}$ This principle is also well established within the practice of statutory interpretation. The rules purporting to resolve chronological antinomies, such as the maxims leges posteriores priores contrarias abrogant and generalia specialibus non derogant, can be justified by the principle that the courts should enforce the law that best represent the consent of the majority of the people or of their elected representatives at the time of decision. Consequently, even if conflicting democratically enacted constitutional and legislative norms have some claim to legitimate authority, one cannot infer that the constitution must necessarily prevail over legislation.

Certain constitutional scholars and judges have consequently propounded another strategy. They have argued that judicial review is legitimate when the norms of the written constitution that are used as reasons not to enforce legislation are shown to be democratically superior to legislation. Now, written constitutions can be conceived as embodying the 'true', the 'highest' or the 'best' will or judgement of the people, despite what they explicitly establish in their legislation through their elected representatives. I shall call theses of this sort the 'Sophisticated View'. This view may take various forms. For example, Bruce Ackerman has explained the democratic superiority of the American Constitution by reference to the quality of the deliberative processes that have led to its popular ratification. In his view, constitutional values result from rare moments of 'higher lawmaking' entrenching the considered judgements of the mass of mobilized citizens debating together, as opposed to legislation which merely reflects the daily work of politicians who speak through institutions that normally do not 'truly' represent the citizens. ${ }^{21}$ Alternatively, the democratic superiority of the constitution has been explained by the fact that this text would express the most enduring or fundamental or important values of the people or the values people hold or ought to hold as morally superior. ${ }^{22}$ But in all cases, the original democratic will or judgment embodied in the constitution is conceived as morally entitled to trump subsequent inconsistent democratic will embodied in legislation.

The various versions of the Sophisticated View are complex indeed and highly controversial on their merit. The question I want to address is the following. Assuming that one version has succeeded in establishing the superior democratic credentials of the constitution over legislation, would it follow that the specific legitimacy of judicial review or its democratic credentials have been established? One might doubt so. There are at least two compelling objections against an affirmative answer to this question (these objections can also be opposed to the Traditional and the Dominant Views). First, the Sophisticated View must necessarily presuppose that the meaning of constitutional norms has been fixed and determined by the language of the constitution, so that judges can discover it

\footnotetext{
${ }^{20}$ Ibid.

${ }^{21}$ Ibid at 1049. See also B. Ackerman, We the People: Foundations (Cambridge: Harvard University Press, 1991).

${ }^{22}$ One version might be found in Bickel, above $\mathrm{n} 1$.
} 
and apply it to relevant cases. It is only if the norms of the written constitution provided formal reasons for decision that judicial review based upon them can be accepted as legitimate within the Specific Legitimacy Thesis. Otherwise, the reasons that would justify the courts to set aside democratically enacted legislation might not derive from the democratically superior constitution. I shall call this the 'Formalist Condition'.

On various occasions, scholars, judges and constitutional lawyers have believed that the Formalist Condition could be satisfied. For example, Chief Justice Marshall's theory of legal meaning and interpretation came within formalism, although not within strict constructionism. ${ }^{23}$ Nevertheless, it has become very difficult to accept the validity or truth of formalism. It is generally admitted that constitutional language is vague, abstract and general and makes at least certain constitutional provisions indeterminate. Accordingly, this language must be interpreted or constructed on grounds of values that are not explicit in the formal constitutional text. Since constitutional interpretation raises deep controversial issues of social policy and political morality, judicial review of legislation might ultimately reflect the courts' own perspectives, preferences and interests or the perspectives, preferences and interests of groups that have the most powerful voice in courts or in society. It follows that the reasons that are used by the courts to justify their decisions not to enforce democratically enacted legislation might not be legal within the ambit of SLT2 nor legitimate within the ambit of SLT4. Indeed, since judges must determine for themselves the kinds of considerations that are sufficiently strong to justify their decisions not to enforce legislation, they raise the spectre of judicial 'super-legislature'.

This objection is particularly powerful in countries where judges explicitly recognize the indeterminate character of constitutional language and their right to find values in sources that lie outside the written constitution. The Canadian Supreme Court, for example, has admitted that certain constitutional clauses are 'vague' and 'open', ${ }^{24}$ that a 'single incontrovertible meaning is not apparent from their language', ${ }^{25}$ that the 'historical usage of the terms used is shrouded in

\footnotetext{
${ }^{23}$ In Marbury v Madisson, above n 9, for example, Chief Justice Marshall insisted on the 'written' character of the Constitution and on the possibility for the courts to 'say what the law is', suggesting thereby that he believed in 'declaratory theory'. He examined the 'obvious meaning' of the words and the formal logic of the constitutional text so as to ascertain the original intention: ibid, at $174-75$ and $177 \mathrm{ff}$. In Osborn v Bank of the United States, 9 Wheaton $738(1824)$ at 866, he said that 'Judicial power, as contradistinguished from the powers of the laws, has no existence. Courts are mere instruments of the law, and can will nothing. When they are said to exercise a discretion, it is mere legal discretion, a discretion to be exercised in discerning the course described by law; and, when that is discerned, it is the duty of the court to follow it. Judicial power is never exercised for the purpose of giving effect to the will of the judge; always for the purpose of giving effect to the will of the legislature; or, in other words, to the will of the law'. In McCulloch v Maryland, 17 U.S. 316 (1819), Marshall said: 'A constitution, to contain an accurate detail of all subdivisions of which its great powers will admit, and of all the means by which they may be carried into execution, would partake of the prolixity of a legal code, and could scarcely be embraced by the human mind. It would probably never be understood by the public. Its nature, therefore, requires, that only its great outlines should be marked, its important objects designated, and the minor ingredients which compose those objects be deduced from the nature of the objects themselves. That this idea was entertained by the framers of the American constitution is not only to be inferred from the nature of the instrument, but from the language. ... [W] must never forget, that it is a constitution we are expounding'. [emphasis added].

${ }^{24}$ Hunter v Southam Inc [1984] 2 SCR 145 at 154.

${ }^{25}$ Re B.C. Motor Vehicle Act [1985] 2 SCR 486 at 501.
} 
ambiguity'26 or that they are devoid of 'particular historical, political or philosophic context capable of providing obvious gloss on their meaning'. ${ }^{27}$ It has conceded that the substance of constitutional norms cannot be determined by recourse to a dictionary or by reference to the rules of statutory construction. ${ }^{28} \mathrm{It}$ has admitted that relevant statements and speeches by prominent figures are 'inherently unreliable ${ }^{29}$ and that the 'intent' of the legislative bodies that adopted the Constitution is a fact which is nearly impossible of proof. ${ }^{30}$ According to the Supreme Court of Canada, the values embodied in the Constitution must not 'become frozen in time to the moment of adoption with little or no possibility of growth, development and adjustment to changing societal needs' ${ }^{31}$ The Constitution is conceived as a 'living tree' and its interpretation must be progressive, purposive and generous. The approach entails a form of analysis that reads the specific provisions in the light of the Constitution's larger objects and its proper linguistic, philosophic and historical contexts. ${ }^{32}$

These propositions may be acceptable from the point of view of constitutional interpretation theory. The problem is that they cannot be reconciled with the Specific Legitimacy Thesis. If it is true that the substance of constitutional rules and principles are not formally determined by the text of the constitution, then one might wonder whether the norms that are used as reason not to enforce legislation are legal within the scope of SLT2 and, if so, whether they can be made legitimate within the scope of SLT4.

These considerations may be sufficient to refute the Sophisticated View. But there is more to say. One might wonder what would be the point of requiring 'original consent' for the purposes of specifically legitimating the constitution. The constitution would draw its moral authority from the fact that it has been explicitly drafted, promulgated, ratified or otherwise explicitly or tacitly agreed to or approved by the people or their elected representatives, but it would possess no properties capable of formally supplying the set of practical reasons that would confer moral legitimacy to judicial review. Original consent would be conceived as a legitimating fact, but it would merely legitimize a formal structure. It would not legitimize the norms that are used by the courts as reasons to set aside legislation. Judges would remain free to read the constitution in a purposive, generous and progressive way, incorporating the values and the norms they believe ought to prevail. One might reply that the process of constitutional interpretation is actually disciplined by a set of institutional constraints. But if judicial decisions not to enforce legislation are based upon reasons that are not legal or, if so, not legitimate within the meaning of the Specific Legitimacy

\footnotetext{
${ }^{26}$ Ibid at 512.

${ }^{27}$ Hunter v Southam Inc, above n 24 at 154.

${ }^{28}$ Ibid.

${ }^{29}$ Re B.C. Motor Vehicle Act, above n 25 at 508.

${ }^{30}$ Ibid.

${ }^{31}$ Ibid at 509.

${ }^{32}$ R. v Big M Drug Mart Ltd [1985] 1 SCR 295 at 344.
} 
Thesis, such institutional constraints cannot count as an argument in favour of the Sophisticated View.

The second objection is more fundamental. Even if the constitution were democratically superior to legislation and, accordingly, should morally prevail in case of conflicts, it would not necessarily follow that the courts should be entitled not to enforce democratically enacted legislation. Other institutions, namely representative legislatures, might be more appropriate forums to make such decisions for the very reason that they best represent the will or the considered judgments of the people or of their elected representatives. Judicial review takes certain controversial political and moral issues out of the public arena where, in a decent democratic society, they should be debated and decided in principle, and transfers them to judges who determine their substance on the basis of standards, values or rights that hardly derive from constitutional provisions. Moreover, judges are not capable of showing other specific moral authorization that could compensate such undemocratic decisions. Finally, there is reason to believe that the elected representatives who have collectively enacted a law apparently inconsistent with constitutional values have reasonably considered them and concluded, after deliberation, that it was desirable to realize the policy, even at the cost of setting aside various aspects of the constitution. Of course, the conclusion remains a matter of judgement and reasonable persons may disagree (indeed, one of the strongest argument in favour of democracy precisely lies in the fact that citizens may reasonably disagree on matter of policy and morality). But there is no reason to believe that the elected representatives are collectively less competent to make such reasonable judgement than judges. It follows that the question of knowing 'who' must interpret the constitution, 'who' must determine its scope of application and 'who' must decide whether it prevails over policies is critical. And, naturally, from the point of view of a democratic legitimacy, this important power should not, in principle, belong to unelected and unaccountable small group of persons.

One might reply that such objection is invalid where the constitution explicitly, or by necessary implication, provides that the courts are entitled to review democratically enacted legislation. I admit that in this case, judicial review would be specifically authorized. But three conditions must be met. First, the constitution must explicitly, or by necessary implication, provide that the courts are entitled to review democratically enacted legislation. Second, it must be shown that the constitution is democratically superior to legislation. Third, the reasons on the basis of which the judiciary may set aside legislation must derive from the constitution. These three conditions are rarely met, if at all.

One might certainly imagine a constitution in which a provision would explicitly provide that the courts are entitled to review democratically enacted legislation on the basis of norms, values and rights they find the most appropriate, just or good, even if they do not lie in the text. Then, the courts would be 'legally' entitled not to enforce legislation on the basis of reasons that are neither 'in' the 
constitution nor democratically determined. But since this power would be explicitly conferred by the constitution which has some higher democratic pedigree, judicial review would have been made legitimate. Yet, this would be wrong. Judicial review would not meet the conditions of the Specific Legitimacy Thesis because the reasons not to enforce democratically enacted legislation would not be legal within the ambit of SLT2 or legitimate within the ambit of SLT4. Judicial review would possess no more democratic credentials than army review or dictator review of democratically enacted legislation to whom the constitution would have explicitly conferred the discretionary power to determine for themselves which democratically enacted legislation should be enforced.

Contemporary constitutional theory has not succeeded to ground the legitimacy of judicial review of democratically enacted legislation within the framework of the Specific Legitimacy Thesis. This does not mean that the project is impossible. But it seems unlikely. Perhaps, this may partly explain why certain authors have abandoned this quest, concentrating their energy to the question of 'what' mode of constitutional interpretation is legitimate, assuming that judicial review is supported, not by moral principles, but by practice, tradition, prudence or result-oriented arguments. Nevertheless, in the next section, I shall put forward one argument showing that judicial review is morally legitimate in principle. This argument does not come within the Specific Legitimacy Thesis. It claims that the courts are invested with some general authority to review legislation purported to be law.

\section{The General Legitimacy Thesis}

In this section, I argue that judicial review is morally legitimate in principle, indeed required, as a matter of political morality. For this purpose, it is necessary to recall that the concept of legitimacy can be understood in different ways. Within political philosophy, legitimacy is generally understood in a special sense. It is a matter for a political action or decision (and more generally, a government) to be specifically authorized by some positive fact (or set of facts) that confers legitimacy. The Specific Legitimacy Thesis expresses this idea within contemporary constitutional theory. Yet, legitimacy can also be understood in a general sense. In this sense, the legitimacy of an act or decision depends on the fact that there is no moral principle entailing that this action or decision is 'impermissible'. In such cases, we might be incapable of finding a moral principle indicating the positive fact by virtue of which the actions or decisions are specifically authorized (that is, made legitimate in a special sense); but we are equally unable to find a moral principle indicating that they are not permissible either. Since the actions and decisions falling within this category are not morally impermissible in principle, we hold, at least in some contexts, that they are 'morally permissible'. This form of legitimacy logically presupposes the existence of at least one general moral principle conferring some general authorization to act 
or to decide, unless some specific moral principles make them impermissible. General principles of this sort ground what I shall call a general legitimacy.

These principles are not easy to demonstrate. They must be reconstructed from what is generally presupposed or implicitly acknowledged within legal and political theory. For example, one may think of the general principle providing that 'what is not morally prohibited is allowed' or the one providing that 'one's freedom stops where the freedom of others begins'. These principles may constitute general principles by virtue of which some acts or decisions are made morally legitimate in a general sense. Equally, Locke's view that in the state of nature everyone has a natural right 'in his own person' making it morally permissible for each individual who mixes his labour with nature, as originally given by God to 'mankind in common', to become the owner of what he has transformed, may be conceived as embodying one principle of general legitimacy. ${ }^{33}$

In some contexts, conformity with a principle of general legitimacy may be acknowledged as plainly sufficient for certain actions or decisions to be morally permissible. In any event, I submit that the legitimacy of judicial review, under certain conditions, belongs to this category. I shall call the reasoning that supports it the 'General Legitimacy Thesis' (GLT). It can be stated in six propositions.

GLT1: All political authorities in a state are bound by a general principle of political morality providing that 'they ought to act, as far as possible, in a legitimate way'.

This general principle of political morality is rarely acknowledged within contemporary constitutional theory. Yet, it has been presupposed by most systematic thinking within normative political philosophy, at least since the works of Jean-Jacques Rousseau and Immanuel Kant. ${ }^{34}$ It is by virtue of this general principle that so much political theoretical work has been concerned with justifying the specific legitimacy of political authority. Indeed, the recurrent debate on the legitimacy of judicial review would be futile without a logically prior commitment to the principle that 'all political authorities in a state ought to act, as far as possible, in a legitimate way'.

\footnotetext{
${ }^{33}$ J. Locke, Second Treatise of Government (1690), ch V. The purpose of chapter V is to show 'how men might come to have a property in several parts of that which God gave to mankind in common, and that without any express compact of all the commoners', ibid, sec. 25. According to him, in the state of nature, man is born 'with a title to perfect freedom, and an uncontrouled enjoyment of all the rights and privileges of the law of nature, equally with any other man, or number of men in the world, hath by nature a power, not only to preserve his property, that is, his life, liberty and estate, against the injuries and attempts of other men; but to judge of, and punish the breaches of that law in others, as he is persuaded the offence deserves, even with death itself, in crimes where the heinousness of the fact, in his opinion, requires it'. Ibid, sec. 87. Similarly, Hobbes' idea that in their natural state, all human beings have complete liberty, that is, 'a right to everything', may arguably be understood as stating one general moral principle of legitimacy. T. Hobbes, Leviathan (1651).

${ }^{34}$ Rousseau opens the first chapter of The Social Contract with these words: 'Man is born free, and everywhere he is in chains. One believes himself the others' master, and yet is more a slave than they. How did this change come about? I do not know. What can make it legitimate? I believe I can solve this question'. J.J. Rousseau, The Social Contract, trans. by V. Gourevitch (Cambridge: Cambridge University Press, 1997) at 41. See also H. Reiss (ed), Kant's Political Writings (Cambridge: Cambridge University Press, 1991).
} 
GLT2: The judiciary, as a matter of fact, exercises political authority in the state. GLT3: Therefore the judiciary ought to act, as far as possible, in a legitimate way.

The reasoning so far establishes that the judiciary is under a basic moral duty, namely the duty to act, as far as possible, in a legitimate way. Accordingly, we must establish the criteria by virtue of which judicial actions and decisions can be acknowledged as morally permissible. Now, as we saw in section I, within modernity, such criteria come within the Specific Legitimacy Thesis. It follows that:

GLT4: The legitimacy of judicial actions and decisions is conditioned by the rule of law (SLT2) provided that the legal reasons for action and decision are legitimate (SLT3) by virtue of some democratic pedigree (SLT4).

GLT5: Accordingly, judicial actions or decisions that are not justified by law or that are based upon legal reasons that are not legitimate within the ambit of the Specific Legitimacy Thesis are not morally permissible.

GLT6: It follows that the judiciary should not recognize as good reasons for action or decision reasons that are not legal (or legally valid) nor legal reasons that are not legitimate.

GLT6 establishes the general legitimacy of judicial review. Of course, it does not indicate any positive fact by virtue of which judicial review would be specifically authorized. But such specific authorization is not required. GLT6 holds true by virtue of the general principle of political morality stated in GLT1. If the courts were to justify their actions and decisions on the basis of considerations that are not legal or on the basis of laws that are not legitimate, they would violate the general principle prescribing that 'all political authorities in a state, including the judiciary, ought to act, as far as possible, in a legitimate way'. It follows that the judiciary is morally entitled, indeed morally required, not to uphold norms that are not legal or laws that not legitimate. Of course, there is no moral rule or principle providing that the courts ought to enforce norms that are not law or laws that are not legitimate. If there were such a principle, it would follow, on the one hand, that the courts would be under a moral obligation to use their own authority to enforce illegitimate laws and, on the other hand, that such judicial decisions would themselves be morally legitimate. Accordingly, totally illegitimate governments could render their own arbitrary decrees morally legitimate merely by having them enforced by the courts. This would be absurd.

It follows that judicial review is morally legitimate in principle. It constitutes the very means, by virtue of which the courts may verify whether an alleged piece of legislation is legal and legitimate and, accordingly, entitled to judicial enforcement, and maintain their own legitimacy. Where it is not, the General Legitimacy Thesis entails that the courts are morally entitled to set it aside in order to comply with their general duty to act, as far as possible, in a legitimate way. The technical devices to achieve such purposes may be of various sorts. Judges may 
invalidate or declare of no force or effect either in part or in totality illegal and illegitimate pieces of legislation, they may regard them as inoperative, they may give them an interpretation that would make them legal or that could enhance their own legitimacy, they may simply ignore their existence, and so on. The right device in any given case should be contextual: it should depend on the kind of illegality and illegitimacy that is at stake.

The fact that judicial review is, under certain conditions, morally permissible does not mean that judges must always refuse to recognize illegal and illegitimate pieces of legislation as reason for decision. It may happen that prudential or pragmatic reasons justify the enforcement of such pieces. For example, if they conclude that declaration of invalidity is likely to provoke social chaos, arbitrary repression, greater injustices, institutional loss of credibility, and so on, it might be better, all things considered, to enforce illegal pieces of legislation or illegitimate laws. ${ }^{35}$ Similarly, the reasoning does not entail that judges are entitled not to enforce particular alleged legitimate laws on weak grounds. Good faith requires judges not to set aside legislation alleged to be illegal or illegitimate unless they are persuaded on balance of reasons that it is not actually legal or legitimate. For this purpose, it should be obvious that a certain rational process of discussion, argumentation and justification must be conducted prior to decision. My argument so far has only been to show that judges are morally entitled not to recognize as good reason for their own decisions norms that are not (or shown not to be) legal and laws that (are shown to) have no legitimacy. No more specific authorization is required. The general principle of political morality requiring all authorities to act, as far as possible, in a legitimate way is plainly sufficient.

The General Legitimacy Thesis entails a certain number of consequences. First, it reverses the burden of justification. Instead of asking the traditional theoretical question: 'By virtue of what specific considerations can judicial review of democratically enacted legislation be legitimized within the Specific Legitimacy Thesis?', the question becomes: 'By virtue of what considerations is legislation alleged to be enforceable by the courts made legitimate?' or 'What conditions must legislation satisfy in order to be (accepted as) legitimate?'. This is an important shift. Within constitutional theory, the burden of showing moral authorization lies upon the judiciary because legislation enacted by a majoritarian democratic body is postulated as legitimate in principle. According to the General Legitimacy Thesis, the judiciary is morally entitled to review legislation in principle for the purposes of maintaining its own specific legitimacy and to set it aside where it appears to be illegitimate. Therefore, the onus of showing that political action and decision is morally permissible rests upon those who claim that an alleged piece of legislation is legitimate.

Second, the General Legitimacy Thesis implies that judges who are asked to enforce particular prescriptions alleged to be legislation must verify beforehand

\footnotetext{
${ }^{35}$ See, for example, the Canadian case, Re Manitoba Language Rights [1985] 1 SCR 721.
} 
whether these prescriptions are morally entitled to be enforced. This presupposes that judges must recognize the existence of certain critical criteria of legitimate legislation, that is, a certain set of norms (principles, standards, rules) that specify the conditions legislation must satisfy in order to be recognized by the courts as morally permissible. Since the observance of these norms is a condition of legitimate legislation and, consequently, of judicial enforcement of legislation, their normative status is logically antecedent to the legislation they define as legitimate. They must be conceived as binding on the basis of reasons that are logically independent from the particular legislation. Ultimately, they derive from the 'best' normative theory of political legitimacy available to judges (whatever this is). ${ }^{36}$ I shall call the norms deriving from this theory the 'antecedent norms with respect to the legitimacy of legislation'.

The antecedent norms, with respect to the legitimacy of legislation, may be of various kinds. Formally, they may relate to the composition, structure or definition of legitimate legislative bodies, to the procedures or the 'manner' that may confer legitimating force to legislative outcomes, to the form legislative enactments must take in order to be legitimate and/or to the content, substance or 'subjectmatter' legislation may legitimately deal with. They may directly prescribe the features legislation must possess in order to be legitimate, such as the 'procedural' norm that would prescribe that 'legitimate legislation must have a majoritarian pedigree'. Or they may prescribe them in a less direct way, such as the 'legalist' norm that would prescribe that 'no legislation is legitimate unless it is in accordance with the formal criteria of validity stipulated in the written constitution'. Given the controversial nature of normative theories of political legitimacy, different people may in fact recognize as 'right' competing conditions of legitimacy. Yet, judges who are asked to enforce alleged legislation must act on the basis of norms that are, on balance of reasons, supported by the 'best' normative theory available.

Third, the General Legitimacy Thesis entails that the nature and scope of morally permissible judicial review of legislation directly depends on the substance of the antecedent norms with respect to the legitimacy of legislation. Suppose, for example, that the antecedent norms provided that no alleged legislation is legitimate unless it expresses the will of the majority of the elected representatives of the people. It would follow that alleged legislation that would not express such a will would not be morally entitled to judicial enforcement. The legitimate scope of judicial review would, then, be fixed. The judiciary would be morally entitled to verify whether the alleged legislation they are asked to enforce expresses the will of the majority of the elected representatives and, if it did not, to deprive it of any force or effect (such alleged legislation would be like any other non legal social expressions or prescriptions). Of course, according to this version of majoritarianism, judicial review would be limited to very narrow

\footnotetext{
${ }^{36}$ Indeed, the process of determining the best normative theory of political legitimacy for the purposes of judicial review may be quite complex and likely to be controversial, both in practice and theory. I leave this issue aside.
} 
issues, notably, whether the alleged legislation has the right kind of majoritarian pedigree. ${ }^{37}$ But suppose that the antecedent norms provided that no expression of the will of the majority of the elected representatives of the people is legitimate unless it is consistent with a set of rights-based constraints. Then the judiciary would be morally entitled to verify whether the alleged legislation expressing the will of the majority of the elected representatives is consistent with the rights that condition its legitimacy. If the alleged legislation was not, then, it would be morally permissible for the judiciary to deprive it of any force or effect. Once again, the normative conditions for the legitimacy of legislation would determine the scope of judicial review and, given the nature of this 'liberal' version of democratic legitimacy, the legitimate scope of judicial review might be quite broad.

These examples are simple cases indeed and we have good reasons to believe that the conditions of legitimate legislation are much more complex. Nevertheless, they illustrate that the proper scope of legitimate judicial review of legislation is determined by or subordinated to the antecedent norms with respect to the legitimacy of legislation, however modest they are. From the standpoint of political morality, there are no more good reasons to require the courts to enforce an alleged piece of legislation that is not morally permissible than to require them to ignore a law that is morally entitled to judicial enforcement. Thus, if a law violating freedom of religion were not morally permissible, then it would be morally permissible for the court not to enforce it to the extent of the violation. The conditions of legitimate legislation would fix the nature and scope of legitimate judicial review.

Fourth, the General Legitimacy Thesis entails that the basic rules and principles of constitutional law providing the criteria of validity and of proper interpretation of legislation derive from the substance of the antecedent norms with respect to the legitimacy of legislation. They are the consequence of prior judicial commitment to enforce the conditions legislation must satisfy in order to be accepted as legitimate. To this extent, they are the result of legitimate legislation.

\footnotetext{
${ }^{37}$ Within British constitutional theory, for example, this form of judicial review has traditionally been conceived as a matter of verifying the 'authenticity', as opposed to the 'validity', of a document alleged to be an Act of Parliament. This test has been designed to verify whether the source of the alleged law is the 'sovereign Parliament' and if the expression of its will is a true 'Act of Parliament'. It has proceeded from a set of 'manner and form' constitutional rules traditionally known as the 'enrolled Act rule'. But this distinction makes true, by definition, the proposition that judicial review of the 'validity' of parliamentary legislation is not permissible in the United Kingdom. It masks the fact that judicial review of what is called the 'authenticity' of legislation is designed to insure that the law that is enforced by the courts is legitimate, at least within the British version of majoritarianism. In Great Britain, thus, judicial review of norms purported to be 'authentic' legislation has a long history. See, for example, The Prince's Case (1606) 8 Co Rep ia, in which it was said that if an Act of Parliament, although found in the Parliamentary Roll, 'be penned, that the King, with the assent of the Lords, or with the assent of the Commons, it is no Act of Parliament, for three ought to assent to it'. See also Edinburgh and Dalkeith Railway Co v Wauchope (1842) $8 \mathrm{Cl}$ \& fin 710 at 724: 'All that a court of justice can do is to look to the Parliamentary Roll: if from that it should appear that a bill has passed both Houses and received the Royal Assent, no court of justice can inquire into the mode in which it was introduced into Parliament, nor into what was done previous to its introduction, or what passed in Parliament during its progress in its various stages through both Houses'; See also Manuel v Attorney-General [1983] Ch 77 at 86: '[O]nce an instrument is recognized as being an Act of Parliament, no English court can refuse to obey it or question its validity ... [T] here has been no suggestion that the copy before me is not a true copy of the Act itself, or that it was not passed by the House of Commons and the House of Lords, or did not receive the Royal Assent. The Act is therefore an Act of Parliament and the court cannot hold it to be invalid'.
} 
I shall call these assertions the 'Constitutional Law Thesis'. I shall examine it in the next section.

\section{The Constitutional Law Thesis}

The Constitutional Law Thesis states that the basic rules and principles of constitutional law providing the criteria of validity and of proper interpretation of legislation derive from the substance of the antecedent norms with respect to the legitimacy of legislation, as understood and enforced by the courts. This is entailed by the General Legitimacy Thesis. This might sound completely heretical. Where the constitution is said to be written, the basic rules and principles of constitutional law relating to the validity and the interpretation of legislation are conceived as contained in foundational documents enacted or ratified by some authorized constituent body. Where the constitution is said to be unwritten, these rules and principles are regarded as contained in the judge-made common law. In the former case, their formal source is the written constitution. In the latter case, the formal source is case law. The material sources of written and unwritten constitutional law are whatever standards, values or norms embodied into its rules and principles. On no account can the rules and principles of constitutional law relating to legislation be conceived as the consequence of prior judicial commitment to enforce the conditions legislation must satisfy in order to be accepted as morally legitimate. Indeed, such rules and principles are generally conceived not as the consequence but as the source of legitimate legislation.

Nevertheless, I want to argue that the Constitutional Law Thesis is plausible whether the rules and principles of constitutional law relating to legislation are written or unwritten. As we saw earlier, the legitimacy of judicial action and decision is conditioned by the rule of law, provided that the legal reasons for such action and decision are legitimate. It follows that judges who are committed to maintain their own legitimacy are morally entitled to verify, prior to act or to decide, whether the alleged legislation they are asked to enforce in particular cases is morally permissible. For this purpose, they must establish the soundest set of antecedent norms with respect to the legitimacy of legislation. These antecedent norms supply the basic conditions legislation must satisfy in order to be accepted as legitimate and, consequently, as morally entitled to judicial enforcement. Ipso facto they settle the conditions legislation must satisfy in order to be recognized by judges as binding for the purposes of executing their own duties and, consequently, as having force or effect 'as a matter of law'. Where the practice of judicial review proceeds within the General Legitimacy Thesis, the substance of the antecedent norms with respect to the legitimacy of legislation constitutes the source, indeed the material source, of the criteria by virtue of which the courts assess the validity and the operative meaning of alleged legislation. It 
constitutes the fundamental basis of the most basic rules and principles of constitutional law relating to legislation. ${ }^{38}$

Suppose, for example, that the antecedent norms with respect to the legitimacy of legislation provided that a given majoritarian institution is morally entitled to make or unmake any law whatsoever. Then all rules prescribed by this majoritarian institution would be morally entitled to judicial enforcement. Suppose also, as a matter of fact, that judges would enforce all such prescriptions. It would follow that judges would recognize these legislative prescriptions as 'valid' and 'operative' as a matter of law. This practice would reveal the existence of at least the following basic rule or principle of the constitution: 'All prescriptions enacted by the relevant majoritarian institution are entitled to be recognized by the courts as having legal force and effect, that is, as legally valid and operative'. Now, this constitutional rule or principle can be either explicitly recognized by judges, as when they explicitly refer to it in the process of justification in particular cases, or implicitly referred to by them, as when they act and decide in accordance with what it prescribes. In the former case, it can be identified as any other explicit legal reason for action and decision. In the latter case, it can be inferred through an analysis and interpretation of the actual practice of judicial review and formulated as a form of 'generalization' drawn from the decisions of the courts. ${ }^{39}$

The same reasoning applies to all kinds of rules and principles of constitutional law deriving from antecedent norms with respect to the legitimacy of legislation. So, if the antecedent norms with respect to the legitimacy of legislation provided that no law is morally entitled to judicial enforcement unless it complies with freedom of expression, such norms would entail that legislative prescriptions inconsistent with freedom of expression would not be morally entitled to judicial enforcement. Accordingly, judges committed to maintain their own legitimacy should not give any force or effect to such prescriptions. To put it in legal terms, they should regard them as 'inoperative' or 'invalid'. For this purpose, they may explicitly recognize one basic rule of the constitution providing that no legislative prescription is legally valid or operative unless it complies with freedom of expression. Otherwise, they would act in such a way that one could infer such basic rule of the constitution as a generalization from judicial actions and decisions.

It does not matter, for the moment, whether the antecedent norms with respect to the legitimacy of legislation are called 'meta-constitutional principles', 'supra-constitutional principles' or 'principles of political morality', 'fundamental law', 'fundamental common law' or 'fundamental principles of common law',

\footnotetext{
${ }^{38}$ The criteria by virtue of which the courts assess the validity and the operative meaning of alleged legislation are formulated as constitutional rules and principles. They constitute the body of 'antecedent rules with respect to the validity of legislation' and 'antecedent rules with respect to the interpretation of legislation'. I have examined them in details in Tremblay, above $\mathrm{n} 7, \mathrm{ch} 3$.

${ }^{39}$ This possibility raises difficult epistemological issues discussed within legal theory. It is not necessary, for my purposes, to discuss them.
} 
'general principles of law' or 'general principles of constitutional law', 'unwritten constitutional law' or 'structural constitutional principles'. All these phrases are acceptable insofar as they represent the idea of a 'law behind the law' (whatever that specifically means), that is, a set of norms logically antecedent and superior to the positive rules and principles of constitutional law it supports. Indeed, they can be misleading insofar as they may underestimate the closeness of the conceptual link between the nature and content of the conditions of political legitimacy of legislation and the nature and content of the rules and principles of the constitution prescribing the criteria of legal validity and operation of legislation.

I said that the Constitutional Law Thesis is plausible whether the constitution is said to be written or unwritten. I now want to substantiate this claim. My purpose is not to show that written and unwritten rules and principles of the constitution have been actually conceived by constitutional theorists and judges as deriving from a set of antecedent norms with respect to the legitimacy of legislation, as understood and enforced by the courts. It is to show that the Constitutional Law Thesis makes sense whether the constitution is said to be written or unwritten.

\section{A. The Hypothesis of Unwritten Constitution}

Unwritten constitution refers to the body of judge-made legal rules and principles specifying the criteria of validity and criteria of proper interpretation of legislation that are conceived as embodied in the case law. Perhaps the only nation in the world that has an unwritten constitution understood in this sense is the United Kingdom. Nevertheless, I want to argue that the Constitutional Law Thesis is plausible where the constitution is mostly unwritten. In what follows, I will examine the validity of this claim in the light of the model of constitutionalism put forward by the most influential British theorist in modern times, Albert V. Dicey. ${ }^{40}$ My purpose is not to show that Dicey's description of the British Constitution was altogether true, or that it was perfectly coherent. I only want to show that Dicey's model of constitutionalism, if true, both supports and is supported by the Constitutional Law Thesis.

Dicey argued that the British Constitution had three main characteristics: the sovereignty of Parliament, the rule of law and constitutional conventions. For our immediate purposes, I must examine his view on the rule of law. Dicey argued that the rule of law included three distinct though kindred conceptions. The first two are well-known: absence of arbitrariness and exclusion of wide discretionary power through legality and equality before the law. But the third meaning, much less known, expressed what I take to be Dicey's model of British constitutionalism. It expressed the fact that the laws of the Constitution are not

\footnotetext{
${ }^{40}$ See Dicey, above n 18. For a similar view, see T.R.S. Allan, Constitutional fustice: A Liberal Theory of the Rule of Law (Oxford: Oxford University Press, 2001).
} 
the source but the result of judicial decisions determining the rights of private persons in particular cases. They are the result of the ordinary law of the land:

We may say that the constitution is pervaded by the rule of law on the ground that the general principles of the constitution (as for example the right to personal liberty, or the right of public meeting) are with us the result of judicial decisions determining the rights of private persons in particular cases brought before the courts; ... [The constitution is] the fruit of contests carried on in the courts on behalf of the rights of individuals. Our constitution, in short, is a judge-made constitution, and it bears on its face all the features, good and bad, of judge-made law.... [I]n England, the so-called principles of the constitution are inductions or generalisations based upon particular decisions pronounced by the courts as to the rights of given individuals.... [W] ith us the law of the constitution, the rules which in foreign countries naturally form part of a constitutional code, are not the source but the consequence of the rights of individuals, as defined and enforced by the courts; ... thus the constitution is the result of the ordinary law of the land. ${ }^{41}$

These passages might be open to interpretation. My own reading is that they suggest that the principles of constitutional law are the result of judicial decisions determining the legitimacy of the political action and decisions judges are asked to enforce. They suggest that the rules and principles of constitutional law are the result of prior judicial commitment to political legitimacy.

Indeed, Dicey was a 19 th century legal positivist. ${ }^{42}$ His project was to describe the positive laws of the constitution as they were, to arrange them in their order, to explain their meaning, to exhibit their logical connection and to discuss their formal sources. ${ }^{43} \mathrm{He}$ was not concerned with the normative constitutional theory or the political philosophy that could have guided judicial practical reasoning in the process of constitution-making. ${ }^{44}$ But suppose that his description of the third meaning of the rule of law was true, that is, that it was a fact that judges were committed to secure rights to individuals. The questions then would be: how could we explain this fact? How could we make it practically intelligible? What can explain the fact that judges were committed to protect certain rights and freedoms, as opposed to others? For the courts could have decided that governmental actions and decisions override all inconsistent individual interests. Dicey's own positivist answer could have been simply that certain rights and freedoms were protected by the ordinary law of the land. But this was questionbegging. Why would such rights and freedoms, as opposed to all others, be protected by the ordinary law of the land so as to be upheld against inconsistent governmental actions and decisions? No individual interest is naturally or logically

\footnotetext{
${ }^{41}$ Ibid, at 195, 196, 197-98, 203.

${ }^{42}$ I have discussed Dicey's positivism in L.B. Tremblay 'La théorie constitutionnelle et la primauté du droit' (1994) 39 McGill LF 101.

${ }^{43}$ See Dicey, above n 18 at 32-34. Yet, Dicey could not avoid showing that the British Constitution was a good constitution. For example, he argued at length that basic political rights and freedoms were better protected in Great Britain by the ordinary law of the land through common law remedy in the courts than by written constitutions that declare rights but do not provide remedies or that could be suspended or taken away by the constituent.

${ }^{44}$ Ibid at $1-35$.
} 
entitled to judicial protection as part of the ordinary law of the land. Such entitlement presupposes judicial choices and decisions. But no such choice or decision can be practically intelligible unless it is supported by reasons that show why it is desirable to protect certain rights and freedoms, as opposed to all others. What considerations can make sense of the judicial choices or decisions to recognize that certain individual interests, as opposed to all others, deserve to be protected against governmental actions and decisions as part of the ordinary law of the land?

The answer might be complex. But I contend that the most important reasons are normative. Ultimately they lie in a certain moral conception of legitimate political action and decision. Indeed, such a conception might have been more or less articulated by individual judges. But if Dicey's description were true, this moral conception must have postulated something like this: no governmental action and decision is morally entitled to judicial enforcement unless it respects certain individual rights and freedoms. Otherwise, the judicial practice, as described by Dicey, would hardly be practically intelligible. Accordingly, his proposition that 'constitutional law is the consequence of the rights of individuals, as defined and enforced by the courts' ultimately meant that constitutional law was the consequence of the 'conditions of legitimate governmental actions and decisions', as understood and enforced by the courts.

Of course, the guiding conception of political legitimacy has not been written anywhere and judges have rarely expressed it. But it can be inferred from the body of judicial decisions enforcing rights against the government through various legal mechanisms and remedies, read in the light of the political, philosophical and cultural background against which judicial making of the ordinary law of the land and of the law of the constitution has taken place in Great Britain. This conception has supplied the set of antecedent norms with respect to the legitimacy of governmental action and decision, including the norms establishing the kinds of individual interests or rights it is not legitimate for the government to violate. It follows that the basic rules and principles of constitutional law relating to the validity and interpretation of governmental action and decision can be understood as deriving from the antecedent norms of political legitimacy.

Indeed Dicey's model of British constitutionalism, as inferred from his third meaning of the rule of law, was not meant to apply to parliamentary legislation. It purported to explain the source of the rules and principles of constitutional law that governed the Crown and its servants, that is, the government and its administrative branch. Parliamentary legislation was governed by another principle, the sovereignty of Parliament. ${ }^{45}$ According to this principle, Parliament has the power to legislate on any matter whatsoever and no competing authority has the power to legislate and to override or set aside the legislation of Parliament, even where legislation is inconsistent with certain individual rights and freedoms. ${ }^{46}$

\footnotetext{
${ }^{45}$ Ibid, ch 1.

${ }^{46}$ The sovereignty of Parliament meant that Queen in Parliament has, 'under the English constitution, the right to make or unmake any law whatever; and, further, that no person or body is recognised by the law of England as having a right to override or set aside the legislation of Parliament'. See ibid at 39-40.
} 
Since this principle expressed the idea that Parliament was entitled to violate any individual right and freedom, it could hardly be conceived as the consequence of the rights of individuals, as defined and enforced by the courts. Indeed, there exists a tension between the rule of law, as conceived by Dicey, and the sovereignty of Parliament. ${ }^{47}$

Yet, it does not follow that the principle of Parliamentary sovereignty cannot be conceived as a consequence of antecedent norms with respect to the legitimacy of legislation. Indeed, I submit that judicial recognition of this principle both supports and is supported by the Constitutional Law Thesis. Dicey's description of the sovereignty of Parliament was also a particular application of legal positivism to British constitutional law. ${ }^{48} \mathrm{He}$ was not concerned with the kind of normative arguments that could have justified judicial enforcement of all parliamentary legislation. The description was grounded upon analytical and empirical considerations. ${ }^{49}$ In Dicey's view, the sovereignty of Parliament was a 'legal fact' fully recognized by the law of England. ${ }^{50}$ It was inferred from the courts' daily practice of recognizing the authority of all parliamentary enactments that had satisfied certain minimal manner and form requirements. The sovereignty of Parliament did not represent a valid rule of constitutional law; it constituted an empirical generalization drawn from the practice of judicial enforcement of all authentic Acts of Parliament. ${ }^{51}$

Yet, suppose that Dicey's description of the sovereignty of Parliament were true. What considerations can make the practice supporting it intelligible? What can make judicial practice of enforcing parliamentary legislation worth maintaining and promoting by those who participate in this practice? One cannot simply answer that it is by virtue of the practice itself, or of political realities or of an ultimate rule of common law. It would be question-begging. The answer should show the reasons for action that confer intelligibility to this practice. Now, as Neil MacCormick argued, acceptance of the ultimate criteria of validity of legislation is not, from the internal point of view, 'a blind datum, a pure brute fact'; judges 'can and do have reasons for accepting it'. ${ }^{52}$ Of course, such reasons can be of various sorts. But since they are meant to justify judicial acceptance of the criteria of validity of legislation, the most important reasons must be normative, indicating what is desirable in the fact of accepting them. Once again, I contend

\footnotetext{
${ }^{47}$ It will not be necessary to try to reconcile these doctrines in this text.

${ }^{48}$ See above, nn 7 and 42.

${ }^{49}$ Dicey's analytical ground is found in propositions stating, for example, that the 'characteristics of the sovereign Parliament must be deduced from the terms themselves', above n 18 at 87 . Dicey's empirical ground is found in propositions showing, for example, that the existence of parliamentary sovereignty is a 'legal fact', ibid at 39, 68 . The empirical justification has become dominant within positivist British constitutional theory. For example, the basis of the sovereignty of Parliament has been described in terms of 'political fact', as in H.W.R. Wade 'The Basis of Legal Sovereignty' [1955] Camb Lf 172, at 187-89, and in terms of 'ultimate rule of recognition' existing by virtue of some complex social situation in which some people, notably the judges, accept certain the criteria for the assessment of the validity of legislation, as in H.L.A. Hart, The Concept of Law (1961).

${ }^{50}$ Ibid at 39 .

${ }^{51}$ Today, the sovereignty of Parliament is generally conceived as a 'legal' rule. See, for example, E.C.S. Wade and A.W. Bradley, Constitutional and Administrative Law (10th edn, London: Longman, 1985) at 65.

${ }^{52}$ N. MacCormick, Legal Reasoning and Legal Theory (Oxford: Clarendon Press, 1978) at 63.
} 
that they ultimately lie in some moral conception of legitimate political action and decision.

The normative theory of political legitimacy embodied in the practice supporting Dicey's principle of Parliamentary sovereignty has probably evolved, indeed shifted, over centuries and it might be difficult to assert with absolute certainty what it has become. It might have come within a version of the theory of sovereignty expressing the normative idea that those who are political sovereign in the state are somewhat (morally, divinely) entitled to have the expression of their will enforced by the courts. Or it might have come within a version of majoritarianism expressing the idea that the majority of the elected representatives of the people are morally entitled to have the expression of their will enforced by the courts (the legitimate authority of parliamentary legislation would flow from the fact that the House of Commons, the members of which are elected and have to answer to the electorate, has become the centre of power within Parliament). Or it might have derived from a version of utilitarianism expressing the idea that the preferences of the greatest number are morally entitled to govern the law of the community. And so on.

My purpose, however, is not to elucidate the particular conception of political legitimacy that would make the best sense of the British judicial practice of enforcing parliamentary legislation. My claim is that this practice, if correctly described by Dicey, cannot be made practically intelligible unless it is conceived as embodying some normative conception of political legitimacy. Accordingly, the principle of the sovereignty of Parliament, as described by Dicey, can be seen as a consequence of judicial decisions determining the legitimacy of the legislation judges are asked to enforce in particular cases. ${ }^{53}$ Therefore, the principle of Parliamentary sovereignty both supports and is supported by the Constitutional Law Thesis.

Of course, the principle of Parliamentary sovereignty and Dicey's conception of constitutionalism seem contradictory. While the principle of Parliamentary sovereignty entails that legislation violating individual rights and freedoms, even those protected by the ordinary law of the land, is morally entitled to judicial enforcement, the principle of the rule of law entails that the general principles of constitutional law are the consequences of the rights of the individuals, as defined and enforced by the courts. How then could Dicey conceive the sovereignty of Parliament as a general principle of the constitution? Substantially, the two ideas seem to embody two different conceptions of political legitimacy. The sovereignty of Parliament, insofar as it claims that no legislation is legitimate unless it expresses the will or the preferences of some majoritarian authority,

\footnotetext{
${ }^{53}$ This is entirely consistent with Neil MacCormick's statement that ' $[w]$ hat must be essential to the internal aspect of the rule of recognition is some conscious commitment to pursuing the political values which are perceived as underpinning it, and to sustaining in concrete form the political principles deemed inherent in the constitutional order of the society in question'. Ibid at 139-40. Thus, the values that support the legitimacy of parliamentary legislation may be seen as constituting the material source of the constitutional rules and principles that provide the manner and form requirements of 'authentic' and 'valid' legislation. On the issue of 'authenticity' within British constitutional theory, see above n 37 .
} 
seems to come within a version of the theory of sovereignty, majoritarianism or utilitarianism. Dicey's constitutionalism, insofar as it claims that no governmental action and decision is legitimate unless it complies with a certain number of basic rights, seems to come within a version of liberal theory. How could Dicey conceive as coherent his theory of British constitutional law?

One might imagine various answers. But it is not necessary for the purposes of this text to propound a thesis that would reconcile Dicey's conception of parliamentary sovereignty with his conception of constitutionalism. My purpose has been to show that Dicey's own theory of British constitutional law, assuming that his descriptions were true and that the legal practice could be made practically intelligible, can both support and be supported by the Constitutional Law Thesis. My argument has purported to show that the Constitutional Law Thesis is plausible where the constitution is mostly unwritten. It aimed at showing that the basic unwritten rules and principles of constitutional law, including the principle of Parliamentary sovereignty, can be conceived as the consequence of prior judicial commitment to political legitimacy.

\section{B. The Hypothesis of Written Constitution}

We may admit that the Constitutional Law Thesis is plausible where the constitution is unwritten. But almost all nations today have written constitutions. Is the Constitutional Law Thesis plausible where the constitution is said to be mostly written? At first glance, the answer seems to be negative. Written constitutions refer to formal documents conceived as containing the body of legal rules and principles establishing and regulating political institutions. They are generally conceived as the ultimate source of the criteria of validity of legislation. Accordingly, the body of constitutional rules and principles cannot be conceived as deriving from a set of antecedent norms with respect to the legitimacy of legislation, as understood and enforced by the courts. It must derive from the texts 'in' which they are contained. They are not the consequence of prior judicial commitment to enforce the conditions legislation must satisfy in order to be accepted as morally legitimate. They are the consequence of having been embodied 'in' a text by virtue of some act of will or assent made by a constituent body recognized by the courts as having legal and political authority to enact the constitution.

Moreover, insofar as written constitutions are conceived as authoritative by virtue of some act of will or assent made by a constituent body recognized by the courts as having legal and political authority to enact the constitution, they are generally conceived as the very source of legitimate legislation. They provide the set of formal, procedural and substantive conditions legislation must satisfy in order to be accepted as morally entitled to judicial enforcement. Thus, if a written constitution provides that "no legislation is valid law unless it possesses some democratic pedigree', the legitimating force of this condition derives from the written constitution itself; it owes nothing directly to the fact that it would be 
morally required by some independent moral principle of democracy. Similarly, if the constitution allowed a legislature to do horrible things, a valid statute prescribing doing such things would be conceived as morally permissible in principle and entitled to judicial enforcement. Legislation, thus, would owe its legitimacy to the fact that its criteria of validity are provided in a written constitution recognized by the courts as authoritative.

This position may be called the 'Standard View' on written constitution. It includes many specific positions, such as the three views examined above, namely, the Traditional View, the Dominant View and the Sophisticated View. If it were well-founded, the Constitutional Law Thesis would hardly be plausible in context of written constitution. But the Standard View is somewhat misleading. First, the Standard View postulates that the legitimacy of written constitutions is source-based. However, it does not specifically require a particular source. Accordingly, since the source could either be a King, an Imperial Parliament, a whole people, their elected representatives, a dictator, an army, and so on, the Standard View may make legitimate any possible form and content of written constitutions. But this would add nothing to the legalist proposition that written constitutions have legitimate force simply by virtue of their existence. This cannot be right from the point of view of political morality. Source-based theses on legitimacy must identify the kinds of source that have legitimating force. Similarly, judicial acceptance of a written constitution as legitimate law must be based upon reasons that justify its normative force. At least one consideration must indicate why it is desirable to accept it as the supreme law of the land. At least one consideration must show why the fact that the written constitution has a particular source constitutes a good reason to recognize it as legitimate and supreme. ${ }^{54}$

This argument can be generalized. Judicial enforcement of a particular text alleged to be the supreme law of the land necessarily requires the acceptance or the existence of a set of antecedent norms specifying the formal, procedural or substantive features written constitutions must possess in order to be accepted as binding law. Since the observance of these norms is a condition for alleged written constitutions to be recognized as binding by the courts, their normative status is logically antecedent to and independent from the constitutions recognized by the courts as entitled to be enforced. But what are these norms? Where should the courts look at in order to find or construct them? Once again, the answer must lie in the normative theory of political legitimacy that appears to be the most justified for the purposes of establishing the legitimacy of written constitutions. I shall call these norms the 'antecedent norms with respect to the legitimacy of written constitution'.

Second, the Standard View postulates that written constitutions provide the criteria by virtue of which the legal validity of legislation is assessed. These

\footnotetext{
${ }^{54}$ For example, in the United States, Chief Justice Marshall claimed, in accordance with the Dominant View, that the legitimacy of the written constitution derives from the fact that the people who ratified it had an original right to make it: above $\mathrm{n} 11$.
} 
criteria are conceived as contained 'in' or formally determined 'by' the written constitution. It follows that the text must possess the kind of properties that fix and determine its 'true' meaning. Now, as we saw, the meaning of written constitutions is rarely fixed or determined solely by its language. ${ }^{55}$ It rather results from a complex process of constitutional interpretation in which judges must refer to values and considerations that cannot be honestly conceived as 'in' or as deriving from values or considerations that are 'in' the text. Constitutional meaning, thus, is generally conditioned by values or considerations that are not 'in' the text. But if this is the case, these values or considerations must justify the normative force of particular constitutional interpretations, as opposed to all others. They must indicate why particular interpretations, and not others, are worth being recognized by the courts as (part of) written constitutional law. Otherwise, they would be purely rhetorical. The process of constitutional interpretation, thus, necessarily requires the acceptance or the existence of a set of antecedent norms specifying the features particular constitutional interpretations must possess in order to be recognized by the courts as binding. Since the observance of these norms is a condition for plausible interpretations to be accepted as valid constructions of the written constitution, their normative status is logically antecedent to and independent from the particular interpretation recognized by the courts as entitled to be enforced in a given case. What are these norms? Where should the courts look at in order to find or construct them? The answer lies again in the normative theory of political legitimacy that appears to be the most justified for the purposes of establishing the legitimacy of written constitutional law. It is to be found in the antecedent norms with respect to the legitimacy of written constitution.

It follows that judicial acceptance of particular texts as valid constitutions, as well as particular constitutional interpretations as correct, must come within a set of logically antecedent norms with respect to the legitimacy of written constitution. This set of norms must specify the features constitutional rules and principles must possess in order to be recognized by the courts as binding and entitled to enforcement as supreme law of the land. But what is the content of such antecedent norms with respect to the legitimacy of written constitution? We saw that it must derive from normative political theory. But what features written constitutions and specific constitutional interpretations must possess in order to be accepted as legitimate and morally entitled to judicial enforcement? This has been one of the most important and difficult question within contemporary normative constitutional theory.

According to the Standard View, the criteria of legitimate constitutional rules and principles are source-based. Constitutional rules and principles cannot be accepted as legitimate by the courts unless they have been willed, consented to or ratified by some constituent political authority recognized as having legitimating force. Accordingly, judicial acceptance of such rules and principles has

\footnotetext{
${ }^{55}$ See above nn 23-32 and accompanying text.
} 
generally been justified in terms of some version of 'originalism': as a theory of authority, it has generally come within 'sovereignty', 'social contract' or 'consent' theory; as a theory of constitutional interpretation, it has generally come within 'original meaning', 'original intent', 'original purpose' and 'original structure' theory. ${ }^{56}$ But there is nothing logical or natural in source-based theory of constitutional legitimacy. Indeed, constitutional legitimacy could be contentbased. It could depend on the substantive quality of the constitutional rules and principles the judiciary is called to enforce as the supreme law of the land, that is, on the character of the values these rules and principles embody or the sort of state they purport to establish, as assessed in accordance with some formalprocedural and/or substantive-purposive criteria of political legitimacy.

According to the Constitutional Law Thesis, the criteria of legitimate constitutional rules and principles dealing with legislation are content-based. Constitutional rules and principles cannot be accepted as legitimate by the courts unless their content is shown to be consistent with the substance of the antecedent norms with respect to the legitimacy of legislation. With respect to written constitutions, this entails that the specific content of the antecedent norms with respect to the legitimacy of a written constitution should be determined in accordance with the substance of the antecedent norms with respect to the legitimacy of legislation. Moreover, judicial recognition of written constitutions as valid and of specific constitutional interpretations as correct should depend on their conformity with the substance of the antecedent norms with respect to the legitimacy of legislation. Accordingly, the basic rules and principles of constitutional law providing the criteria of validity and of proper interpretation of legislation should derive from the conditions legislation must satisfy in order to be accepted by the courts as morally permissible and entitled to judicial enforcement. They should be the consequence of legitimate legislation, as understood and enforced by the courts for the purposes of maintaining their own legitimacy in accordance with the General Legitimacy Thesis. Is this a plausible position?

In the remainder of this text, I want to argue that the Constitutional Law Thesis is plausible even where the constitution is said to be mostly written. I shall examine the validity of this argument in the light of a certain number of influential contemporary constitutional theories. My purpose is not to show that one or many of these theories are true or that they are perfectly coherent. I only want to show that these theories, if true, would both support and be supported by the Constitutional Law Thesis.

It has been argued, within contemporary constitutional theory, that basic rules and principles of written constitutional law dealing with legislation should be

\footnotetext{
${ }^{56}$ The Traditional View claims that it is sufficient for the constitution to have been enacted by an authoritative constituent body; the Dominant View claims that it is sufficient for the written constitution to have a democratic pedigree, such as the fact of having been enacted or ratified by a democratic constituent body; the Sophisticated View claims that it is sufficient for the written constitution to have a pedigree that is democratically superior to all others political actions and decisions, such as being enacted or ratified by an institution that is more representative than other political institutions or that reflects the best will or the most considered judgements of the people. See above section 1 .
} 
conceived as 'enabling', not disabling, even where they put limitations upon legislative institutions. These rules and principles are those that are necessary to create, maintain and enhance democracy (whatever that means for the moment). It follows that constitutional constraints and restraints, including provisions protecting basic rights and freedoms, would be morally entitled to judicial enforcement but only to the extent to which they can be conceived as 'democracy-reinforcing'. Of course, the theories that share this view do not agree as to what specific normative democratic standards can explain and justify the normative force of particular constitutional rules and principles. But they all agree that they should derive from democratic theory, indeed, from the best theory of democratic legitimacy available. They all agree, accordingly, that the courts should read the written constitutions as if they embodied the best normative conception of democracy, even at the cost of departing from originalism. I shall call them 'democracy-reinforcing theories'.

Suppose that the best conception of democratic legitimacy came within an utilitarian or pluralist conception of representative democracy similar in principle to that of John Hart Ely. ${ }^{57}$ The judiciary would then be entitled to review legislation in accordance with Ely's participation-oriented and representationreinforcing approach, as opposed to an approach based upon the judicial determination and imposition of substantive values. Where constitutional provisions are 'open-ended', ${ }^{58}$ the courts would be entitled to interpret them in accordance with process values even if they are not found within the four corners of the document. One reason derives from the fact that the general structure of the American Constitution is not concerned with substantive values; it is overwhelmingly concerned with procedures, process, participation and representation. ${ }^{59}$ This concern has been pursued by establishing a structure of government by virtue of which the elected representatives are able to enact substantive policies in a democratic way instead of being disabled from doing it. But there are normative reasons, 'if anything more important than the one ... just reviewed', in favour of the participation-oriented and representation-reinforcing approach to judicial review. ${ }^{60}$ One of them is that this approach, 'unlike its rival value-protecting approach, is not inconsistent with, but on the contrary (and quite by design) entirely supportive of, the underlying premises of the American system of representative democracy'. ${ }^{61}$ It follows that judicial review based upon constitutional interpretations that contribute to improving participation and representation by correcting the malfunctioning of the democratic process, such as when certain groups are systemically excluded or when some rights critical to the proper functioning of an open and effective democratic process have been infringed upon, is

${ }^{57}$ J.H. Ely, Democracy and Distrust (Cambridge: Harvard University Press, 1980). See also J.H. Ely 'Democracy and Judicial Review' (1982) 17 Stanford Lawyer 3, reprinted in J.H. Ely, Constitutional Ground (Princeton: Princeton University Press, 1996) at 6-16.

${ }^{58}$ See, for example, ibid ch 2 .

${ }^{59}$ Ibid at $88-101$.

${ }^{60}$ Ibid at 101 .

${ }^{61}$ Ibid at 88 . 
plainly acceptable. ${ }^{62}$ Conversely, it is not acceptable to the extent to which it is based upon rules and principles that allow the courts to review the substantive policy choices made by the majority of the elected representatives. ${ }^{63}$

But suppose that the best conception of democratic legitimacy available came within some republican conception of democracy, something along the lines put forward by Frank Michelman. ${ }^{64}$ Then, the point of democracy would be to enhance self-government and jurisgenerative politics, that is, positive freedom in the modern context of equality of respect, liberation from ascriptive social roles, and plurality of perspectives. ${ }^{65}$ Accordingly, legitimate legislation would depend on certain dialogic-republican conditions and the courts would be entitled to set aside legislation that would run counter this version of the republican state. For this purpose, the courts would be entitled to read the Constitution as embodying the set of social and procedural conditions of jurisgenerative popular engagement, such as the process of 'personal self-revision under social-dialogic stimulation' ${ }^{66}$ One might characterize as 'process-based' this form of judicial review, as Michelman claims, but it would not be limited to Ely's idea of 'representationreinforcing' ${ }^{67}$ Many substantive choices made by the majority of the elected representatives could form a legitimate object of judicial review. ${ }^{68}$

Similarly, if the best conception of democratic legitimacy came within some deliberative conception of democracy, then the quality of the process of public deliberation would be a necessary condition of legitimate legislation. ${ }^{69}$ This might be interpreted in various ways, according to what is regarded as conferring the process of deliberation its legitimating force. According to Cass Sunstein, for example, 'a constitution should promote deliberative democracy, an idea that is meant to combine political accountability with a high degree of reflectiveness and a general commitment to reason-giving' ${ }^{70}$ This is consistent with judicial

\footnotetext{
${ }^{62}$ Ibid chs 4-6.

${ }^{63}$ Ely agrees with Justice Linde's following assertion: 'As a charter of government a constitution must prescribe legitimate processes, not legitimate outcomes, if like ours (and unlike more ideological documents elsewhere) it is to serve many generations through changing times'. Linde 'Due Process of Lawmaking' (1975) 55 Neb L Rev 197 at 254 .

${ }^{64}$ Michelman 'Law's Republic' (1988) 97 Yale Lf 1493 at 1526.

65 'Jurisgenerative' politics is defined as 'a process in which private-regarding 'men' become public-regarding citizens and thus members of a people. It would be by virtue of that people-making quality that the process would confer upon its law-like issue the character of law binding upon all as self-given'. See Michelman, ibid, at 1502, 1513-15. The term is borrowed from Cover 'The Supreme Court, 1982 Term - Foreword: Nomos and Narrative' (1983) 97 Harv L Rev 4.

${ }^{66}$ Ibid at 1528. In this way, the courts may legitimately challenge the people's 'self-enclosing tendency to assume their own moral completion as they now are and thus to deny to themselves the plurality on which their capacity for transformative self-renewal depends'. Ibid at 1532. See also Michelman 'Foreword: Traces of Self-Government' (1986) 100 Harv L Rev 4.

${ }^{67}$ Ibid, at 1525: 'Republican constitutional jurisprudence will to that extent be of the type that Laurence Tribe calls (and criticizes as) 'process-based".

${ }^{68}$ See, for example, the 'process-based' justification of privacy rights in Michelman, ibid, at $1532 \mathrm{ff}$.

${ }^{69}$ On deliberative democracy theory, see, for example, the texts in J. Bohman, W. Rehg (eds), Deliberative Democracy (Cambridge: MIT Press, 1997); J. Elster (ed), Deliberative Democracy (New York: Cambridge University Press, 1998); A. Duhamel, D. Weinstock and L.B. Tremblay (eds), La démocratie délibérative en philosophie et en droit (Montreal: Thémis, 2001) and the bibliography in this book at 255-74. My own contribution to deliberative democracy theory is found in L.B. Tremblay 'Deliberative Democracy and Liberal Rights' (2001) 14 Ratio furis 424.

${ }^{70}$ C. Sunstein, Designing Democracy. What Constitutions Do (Oxford: Oxford University Press, 2001) at 6-7. See also C. Sunstein, The Partial Constitution (Cambridge: Harvard University Press, 1993).
} 
protection of rights that are preconditions for the deliberative process and may justify judicial promotion of widespread participation by free and equal citizens. The judiciary should be used, 'not simply to 'block' democracy but to energize it and to make it more deliberative' ${ }^{71}$ In my view, the basic conditions of legitimate lawmaking within deliberative democracy theory entail furthermore that legislation must be supported by reasons that are both valid and capable of being accepted as sufficient by actual citizens, notably by those who are affected by it. ${ }^{72}$ These criteria, although 'procedural' in nature, may also justify judicial review of many substantive choices made by the majority of citizens.

Now, suppose that the best understanding of democratic legitimacy came within some liberal or constitutional conception of democracy. Then respect for a set of basic individual rights and freedoms would be conceived as a necessary condition of legitimate legislation and the courts would be entitled not to enforce alleged legislation interfering with liberal rights or freedoms. Ronald Dworkin's constitutional conception of democracy illustrates this point. His conception provides that political legitimacy is conditioned by political institutions whose structure, composition, and practices 'treat all members of the community, as individuals, with equal concern and respect'. ${ }^{73}$ This entails that political institutions must be chosen in accordance with, and once chosen, must be subject to democratic conditions of equal status for all citizens. Such conditions are the conditions of moral membership in a political community ${ }^{74}$ They are 'structural' when they describe the general character a community must have in order to be a genuine political community and 'relational' when they describe how individuals must be treated in order to be moral members of that community. No individual can count as a moral member unless he or she has 'a part in any collective decision, a stake in it, and independence from it'. ${ }^{75}$ Where these conditions are satisfied, the people within constitutional democracy govern 'communally' as a special, distinct and collective unit of responsibility. It follows that the courts are entitled to read the relevant provisions of the written Constitution as committed to this moral conception of constitutional democracy. Indeed, such moral reading of the Constitution, as well as judicial decisions to set aside legislation that interferes with the rights and freedoms that condition its legitimacy, cannot be seen as antidemocratic:

If the court's decision is correct ... the decision is not antidemocractic, but, on the contrary, improves democracy. No moral cost has been paid, because no one, individually or collectively, is worse off in any of the dimensions we have now canvassed ... If the court had not intervened - if the legislature's decision had been

${ }^{71}$ Ibid at 241 .

${ }^{72}$ I have explored this theme in L.B. Tremblay, 'La démocratie délibérative et la protection des intérêts fondamentaux' in A. Duhamel, D. Weinstock and L.B. Tremblay, above n 69 at 163. See also, Tremblay, above n 69.

${ }^{73}$ R. Dworkin, Freedom's Law. The Moral Reading of the American Constitution (Cambridge: Harvard University Press, 1996) at 17.

${ }^{74}$ Ibid at 24.

${ }^{75}$ Ibid. See also at 23-6. 
left standing - everyone would have been worse off, in all dimensions of democracy, and it would be perverse to regard that as in any way or sense a democratic victory. Of course, if we assume that the court's decision was wrong, then none of this is true. ${ }^{76}$

In the light of Dworkin's liberal or constitutional interpretation of democracy, the judiciary could be quite interventionist. ${ }^{77}$ It would be concerned not only with democratic process and participation, but with substance, justice and political decency as well.

These democracy-reinforcing theories, among others, both support and are supported by the Constitutional Law Thesis. They support and are supported by the claim that the substance of basic rules and principles of constitutional law dealing with legislation must be determined in accordance with the set of norms that specify the formal, procedural or substantive features legislation must possess in order to be recognized by the courts as morally entitled to judicial enforcement. Democracy-reinforcing theories suggest that the substance of the rules and principles of written constitutions must derive (or ought to derive) from the substance of antecedent norms with respect to the legitimacy of legislation. Accordingly, they suggest that the substance of constitutional law must result from prior judicial commitment to democratic political legitimacy and that the process of constitutional interpretation must be used by the courts to do the fine-tuning that makes the meaning of the text consistent with the substance of the antecedent norms with respect to the legitimacy of legislation.

Moreover, democracy-reinforcing theories support and are supported by the claim that the antecedent norms with respect to the legitimacy of legislation underlie abstract and concrete constitutional meanings and purposes, as understood and enforced by the courts. These norms can also justify changes in constitutional meaning. They ultimately provide the reasons not to judicially enforce, in particular cases, written constitutional rules generally recognized as 'clear' or to impose new conditions to the application of such clear constitutional rules. They support the 'creation' of new constitutional rules or principles and new particular exceptions to existing constitutional rules and principles. Where the antecedent norms with respect to the legitimacy of legislation constitute a material interpretive source of the written constitution, the law of the constitution may not always be capable of being formally attached to the words of specific provisions. But the Constitutional Law Thesis, like democracy-reinforcing theories, provides that judicial decisions must be justified, not in terms of what the constitution 'really' says or what its words

\footnotetext{
${ }^{76}$ Ibid at 32.

${ }^{77}$ The judiciary would be morally authorized not to recognize as good reason for decision any law that is inconsistent with democratic conditions close to the most basic values of 'liberal democracy'. See, for example, Dworkin's conditions of 'stake' and 'moral independence', ibid at 25-6.
} 
'really' mean, but in terms of what constitutional meaning, rules and principles may make legislation legitimate. ${ }^{78}$

Yet, democracy-reinforcing theories are more limited in scope than the Constitutional Law Thesis. First, these theories have been conceived as competing answers to the question of how the American Constitution should be interpreted. They have not been concerned with the conditions a text alleged to be the Constitution or a valid constitutional amendment must satisfy in order to be accepted by the courts as valid. But this should be understood as a feature of American constitutional law in which, for all practical purposes, the validity of the written Constitution is taken as settled (even by constitutional theorists who disagree with judicial supremacy and judicial review). Yet, their basic commitment to democratic legitimacy makes democracy-reinforcing theories suitable to fix the conditions a text alleged to be the constitution or a constitutional amendment must satisfy in order to be accepted by the courts as valid. Indeed, the Constitutional Law Thesis can explain why.

Suppose that a court committed to democracy-reinforcing theories were asked to recognize and enforce a text dealing with legislation as a valid constitution or as a valid constitutional amendment. How should it proceed to determine what it should do? According to the Constitutional Law Thesis, the guiding principle would be that the recognition should depend on whether the criteria of legal validity of legislation provided by the alleged constitutional text can plausibly be interpreted as creating or contributing to maintain or enhance democracy. Indeed, this might not be a sufficient condition; one might believe that there are other conditions, notably, source-based conditions. But the plausible democracyreinforcing features of the alleged constitutional text should constitute a necessary condition.

For the purposes of determining whether the alleged constitutional text can plausibly be interpreted as creating or contributing to maintain or enhance democracy, the court would not have to determine the specific meaning and scope of each word and provision. It would be sufficient to see whether the

\footnotetext{
${ }^{78}$ Canadian constitutional law provides many examples where the Supreme Court has changed constitutional meaning, refused to enforce, in particular cases, written constitutional rules generally recognized as 'clear', imposed new conditions to the application of such clear constitutional rules, and created new constitutional rules or principles and new particular exceptions to existing constitutional rules and principles. Moreover, many cases can arguably be understood in the light of the Constitutional Law Thesis. The famous cases dealing with the idea of an 'Implied Bill of Rights', promoting freedom of speech and democracy, such as Re Alberta Statutes [1938] SCR 100; Switzman v Elbling [1957] SCR 285; OPSEU v Ontario [1987] 2 SCR 2, are probably the best known. It is true that the legal basis for such decisions has been explained in terms of unwritten principles found in the preamble to the Constitution Act, 1867, that states that the founding provinces 'have expressed their Desire to be federally united into One Dominion ... with a Constitution similar in Principle to that of the United Kingdom'. However, a majority of the Court has recently agreed with Justice Rand who maintained that the preamble articulates 'the political theory which the Act embodies' (see Switzman, ibid at 306). Accordingly, the Court held that the preamble recognizes and affirms the basic principles which are the very source of the substantive provisions of the Constitution Act, 1867: 'As such, the preamble is not only a key to construing the express provisions of the Constitution Act, 1867 , but also invites the use of those organizing principles to fill out gaps in the express terms of the constitutional scheme. It is the means by which the underlying logic of the Act can be given the force of law'. See Reference re Remuneration of fudges of the Provincial Court of Prince Edward Island [1997] 3 SCR 3 at 69. See also, more generally, Reference re Secession of Quebec, above n 14.
} 
general purposes and meaning of the text can prima facie plausibly be interpreted as supporting the conditions of legitimate democratic legislation. If they did, the court would be morally entitled to recognize the text as providing valid constitutional rules and principles. If they did not, then the court would be morally entitled not to recognize the text as morally binding, for its application would entail judicial enforcement not only of a text that would not be democracyreinforcing, but of illegitimate legislation. Thus, if the antecedent norms with respect to the legitimacy of legislation provided that no law is legitimate unless it expresses the will of the majority of the elected representatives and that a court were asked to enforce a text, alleged to be a valid constitutional amendment, purporting to concentrate all legislative powers in the arbitrary hands of a tyrant, the courts would be morally entitled not to recognize the normative force of this alleged constitutional amendment. The same would hold true if the antecedent norms provided that no majoritarian legislation is legitimate unless it respects freedom of religion and that a court were asked to enforce a text, alleged to be a valid constitutional amendment, purporting to establish Catholicism as state religion. ${ }^{79}$

Of course, in most contemporary Western democratic societies, this reasoning sounds rather academic. But this should be explained by the fact that the meanings and purposes of written constitutions and constitutional amendments are generally capable of being understood in terms that are consistent with the conditions legislation must satisfy in order to be accepted as democratically legitimate, whatever such conditions are. This fact might also explain why the courts do not, or very rarely do, refuse to enforce texts alleged to be written constitutions or constitutional amendments and why lawyers generally expect all constitutional amendments enacted in accordance with formal constitutional criteria to be recognized by the courts as valid. But this does not entail that the courts are morally compelled to enforce all such texts in all circumstances.

Second, democracy-reinforcing theories have not been conceived as entailing that judicial review is morally legitimate in principle. Their concern has been to show that judicial review is not inconsistent with democracy when the rules or principles of constitutional law that are used by the courts as reason not to enforce legislation are democracy-reinforcing. It has been to show that, in such cases, democratic values and theory cannot be used as an argument of principle against the practice of judicial review. Dworkin, for example, has conceded that his discussion was limited: he did not offer a positive argument 'in favor of judicial review, either in the form that institution has taken in the United States or in any other form'. ${ }^{80} \mathrm{He}$ simply established 'a level playing field on which the contest between different institutional structures for interpreting the democratic conditions must take place, free from any default or presupposition

\footnotetext{
${ }^{79}$ See, for example, the discussion in S. Freeman 'Original Meaning, Democratic Interpretation, and the Constitution' (1992) 21 Philosophy and Public Affairs 26 at 41-2.

${ }^{80}$ See Dworkin, above n 73 at 33.
} 
whatsoever' ${ }^{31}$ But if such positive argument were needed, Dworkin would use a 'result-driven' standard, rather than a procedure-driven standard: judicial review would be justified if the courts were more likely 'to produce the best answers to the essentially moral question of what the democratic conditions actually are, and to secure stable compliance with those conditions' ${ }^{82}$

By contrast, the Constitutional Law Thesis provides one positive argument showing that judicial review of legislation is morally legitimate in principle. Its legitimacy directly derives from the General Legitimacy Thesis that provides that all political authority, including the judiciary, must act, as far as possible, in a legitimate way. This argument in favour of judicial review is neither resultdriven nor procedure-driven. It is irrespective of whether judicial review is formally authorized by the written constitution. It follows that if the antecedent norms with respect to the legitimacy of legislation embodied the values of democratic legitimacy, as all democracy-reinforcing theories suppose, then the judiciary would be morally entitled, indeed morally required, to read the body of constitutional law as a set of rules and principles that create, maintain and enhance a system of government that is consistent with the conditions of democratic legitimacy. To this extent, democracy-reinforcing theories not only support, but are supported by the Constitutional Law Thesis.

\section{Conclusion}

The main purpose of this text was to provide a general answer to one of the questions that dominate contemporary normative constitutional theory: what can make judicial review morally legitimate in principle? My answer was that judicial review of legislation is legitimized by virtue of one general principle of political morality that provides that 'all political authorities in a state, including the judiciary, ought to act, as far as possible, in a legitimate way'. I have called the argument supporting this answer the 'General Legitimacy Thesis'. The secondary purpose was to draw a certain number of consequences from this thesis, notably on our understanding of the fundamental basis of constitutional law. I argued that the basic rules and principles of constitutional law dealing with the validity and the interpretation of legislation must be conceived as deriving from a set of antecedent norms that provide the conditions legislation must satisfy in order to be accepted as morally legitimate and, consequently, as morally entitled to judicial enforcement. I have called the argument that supports this claim the 'Constitutional Law Thesis'.

The General Legitimacy Thesis and the Constitutional Law Thesis therefore have some bearing on the three other questions that are at the core of contemporary normative constitutional theory. ${ }^{83}$ First, they entail that the main purpose

\footnotetext{
${ }^{81}$ Ibid.

${ }^{82}$ Ibid at 34 .

${ }^{83}$ See my introduction, above.
} 
or function of a constitution, insofar as it deals with legislation, is to make legislation legitimate for the purposes of judicial enforcement of law. A constitution must be understood as expressing or embodying a set of rules and principles providing the criteria of validity and of proper interpretation of legislation that make it morally entitled to judicial enforcement. The basic purpose and function of constitutional rules and principles, thus, is to enable the making of legitimate law. Second, the legitimacy of a constitution partly derives from the fact that it contributes to create, maintain and enhance a system of government that can produce legitimate legislation. The basic ground of the normative force of constitutional rules and principles is not source-based; it is not a matter of will or consent, at least not in an exclusionary sense. It is primarily a matter of content. It is a matter of being in accordance with a set of moral antecedent norms the substance of which determines the conditions of legitimate legislation. Third, constitutional interpretation is made legitimate by virtue of interpretive arguments that contribute to make the rules and principles of constitutional law legitimate, that is, consistent with the antecedent norms with respect to the legitimacy of legislation. Legitimate interpretive arguments must support constitutional interpretations that make legislation morally entitled to judicial enforcement. This applies to written as well as to unwritten constitutional rules and principles.

Therefore, insofar as political legitimacy is conceived as coming within some version of democratic theory, as it is generally postulated within contemporary Western society, the purpose and function of constitutional law dealing with legislation should be conceived as enabling the making of democratic legislation (whatever that means). Furthermore, the legitimate authority of constitutional rules and principles dealing with legislation should depend on whether their enforcement contributes to create, maintain and enhance democratic legislation. Similarly, legitimate constitutional interpretation should depend on whether the norms it entails enable the making of democratic legislation. Where these conditions are satisfied, the constitution can legitimately be characterized as 'democratic', independently of the specific character of its formal source. 